Research review paper

\title{
Aerobic granular sludge: Recent advances
}

\author{
Sunil S. Adav ${ }^{a}$, Duu-Jong Lee ${ }^{\mathrm{a}, *}$, Kuan-Yeow Show $^{\mathrm{b}}$, Joo-Hwa Tay ${ }^{\mathrm{c}}$ \\ a Department of Chemical Engineering, National Taiwan University, Taipei, Taiwan \\ b University of Tunku Abdul Rahman, 13 Jalan 13/6, 46200 Petaling Jaya, Selangor Darul Ehsan, Malaysia \\ ${ }^{c}$ Institute of Environmental Science and Engineering, Nanyang Technological University, Innovation Centre, Block 2, Unit 237, 18 Nanyang Drive, 637723, Singapore
}

\section{A R T I C L E I N F O}

\section{Article history:}

Received 21 February 2008

Received in revised form 10 April 2008

Accepted 6 May 2008

Available online 19 May 2008

\section{Keywords:}

Aerobic granules

Mechanisms

Extracellular polymeric substances

Structure

Interactions

\begin{abstract}
A B S T R A C T
Aerobic granulation, a novel environmental biotechnological process, was increasingly drawing interest of researchers engaging in work in the area of biological wastewater treatment. Developed about one decade ago, it was exciting research work that explored beyond the limits of aerobic wastewater treatment such as treatment of high strength organic wastewaters, bioremediation of toxic aromatic pollutants including phenol, toluene, pyridine and textile dyes, removal of nitrogen, phosphate, sulphate and nuclear waste and adsorption of heavy metals. Despite this intensive research the mechanisms responsible for aerobic granulation and the strategy to expedite the formation of granular sludge, and effects of different operational and environmental factors have not yet been clearly described. This paper provides an up-to-date review on recent research development in aerobic biogranulation technology and applications in treating toxic industrial and municipal wastewaters. Factors affecting granulation, granule characterization, granulation hypotheses, effects of different operational parameters on aerobic granulation, response of aerobic granules to different environmental conditions, their applications in bioremediations, and possible future trends were delineated. The review attempts to shed light on the fundamental understanding in aerobic granulation by newly employed confocal laser scanning microscopic techniques and microscopic observations of granules.

(c) 2008 Elsevier Inc. All rights reserved.
\end{abstract}

\section{Contents}

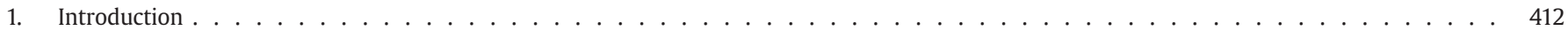

2. Granule formation, characterization, and applications . . . . . . . . . . . . . . . . . . . . . . . . 412

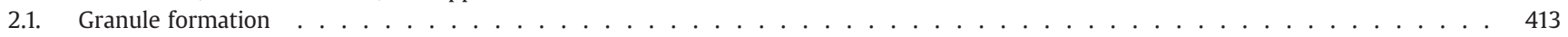

2.1.1. Seed sludge . . . . . . . . . . . . . . . . . . . . . . . . . . . . . . . . . . . . 413

2.1.2. Feed composition . . . . . . . . . . . . . . . . . . . . . . . . . . . . . . 413

2.1.3. SBR operation. . . . . . . . . . . . . . . . . . . . . . . . . . . . . . . . . . . . . . . . . . . . . . . . .

2.2. Granule characterization . . . . . . . . . . . . . . . . . . . . . . . . . . . . . . . . . . . . . 414

2.2.1. Physical parameters . . . . . . . . . . . . . . . . . . . . . . . . . . . . . . . . . . . . . . 414

2.3. Chemical parameters . . . . . . . . . . . . . . . . . . . . . . . . . . . 414

2.3.1. Biological parameters . . . . . . . . . . . . . . . . . . . . . . . . . . . . . . . 415

2.4. Granule applications . . . . . . . . . . . . . . . . . . . . . . . . . . . . . . . . . . . . 4415

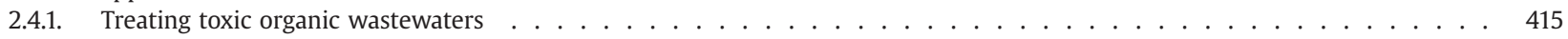

2.4.2. Treating dairy wastewater . . . . . . . . . . . . . . . . . . . . . . . . . . . . . . . . 416

2.4.3. Removal of nitrogen and phosphorus . . . . . . . . . . . . . . . . . . . . . . . . . 416

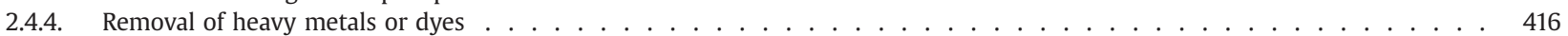

2.4.5. Removing particulate matter . . . . . . . . . . . . . . . . . . . . . . . . . 416

2.4.6. Removal of nuclear waste . . . . . . . . . . . . . . . . . . . . . . . . . . . . . . . . . . . . . . . . . .

Abbreviations: AGSBR, aerobic granular sludge membrane bioreactor; AOB, ammonium oxidizing bacteria; AUFB, aerobic upflow fluidized bed; CLSM, confocal laser scanning

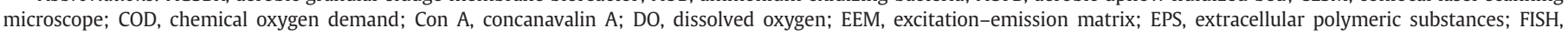

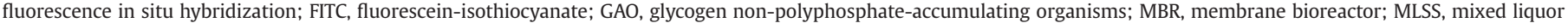

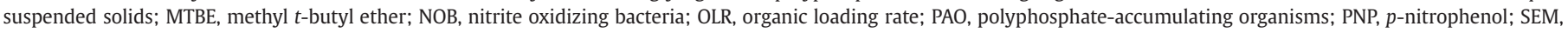

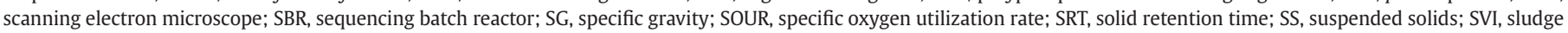
volume index; UASB, upflow anaerobic sludge blanket; VSS, volatile suspended solids.

* Corresponding author. Department of Chemical Engineering, National Taiwan University, Taipei, 10617, Taiwan. Tel.: +886 2 232532; fax: +886 2 23623040.

E-mail address: djlee@ntu.edu.tw (D.-J. Lee). 


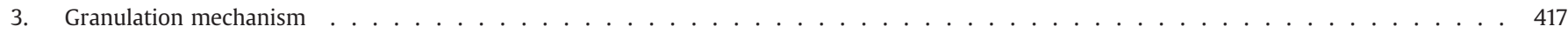

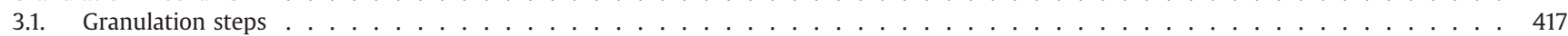

3.2. Selective pressure driven hypothesis . . . . . . . . . . . . . . . . . . . . . . . . . 418

3.3. EPS enhanced granulation . . . . . . . . . . . . . . . . . . . . . . . . . . . . . . . . . . 418

3.4. Granulation models . . . . . . . . . . . . . . . . . . . . . . . . . . . . . . 418

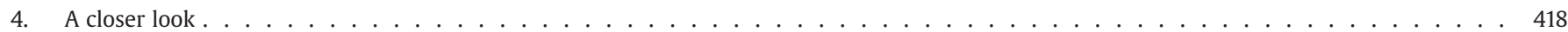

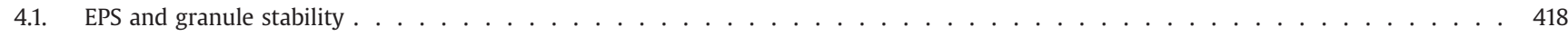

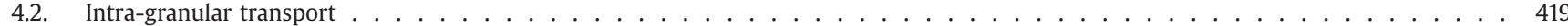

4.3. Strain interactions . . . . . . . . . . . . . . . . . . . . . . . . . . . . . . 419

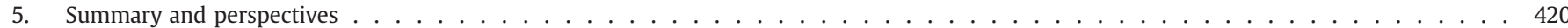

5.1. Thermophilic aerobic granules . . . . . . . . . . . . . . . . . . . . . . . . . . . . . 420

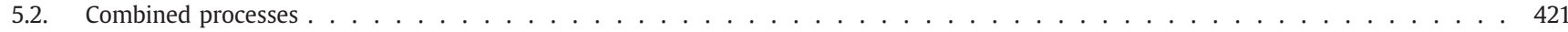

5.3. Cultivation of aerobic granules with genetically engineered microbial species . . . . . . . . . . . . . . . . . . . . . . . . 4421

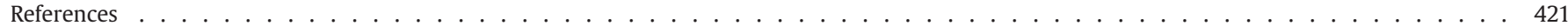

\section{Introduction}

Aerobic granules were considered to be a special case of biofilm composing of self-immobilized cells. During the last 20 years, intensive research in the field of biological wastewater treatment and other applications demonstrated that biofilms were often more efficient for water purification than suspended activated sludge. To date, the application of aerobic granular sludge was regarded as one of the promising biotechnologies in wastewater treatment. The first patent was granted by Heijnen and van Loosdrecht (1998). de Kreuk et al. (2007a,b) provided comments on the state of the art for the aerobic granulation process. Liu and Tay (2004) and Maximova and Dahl (2006) provided an up to date summary of the current understanding towards the bioaggregation processes.

Granular sludge was first described for strictly anaerobic systems in 1980 (Lettinga et al., 1980) and only by the late 1990s had the formation and application of aerobic granules been reported (Morgenroth et al., 1997, Beun et al., 1999, Dangcong et al., 1999). The anaerobic granulation technology exhibited several drawbacks that included a long start-up period, a relatively high operating temperature, unsuitability for low strength organic wastewater, and low efficiency in the removal of nutrients ( $\mathrm{N}$ and $\mathrm{P}$ ) from wastewater. This resulted in the development of aerobic granular technology which became a popular topic of discussion for environmental engineers.

Compact structured, biologically efficient aerobic sludge granules with wide diverse microbial species and excellent settling capabilities have been developed in sequencing batch reactors (SBR) (Morgenroth et al., 1997; Beun et al., 1999; Tay et al., 2001a; Yang et al., 2003; Liu and Tay, 2004, Adav et al., 2007a). Formation by self immobilization of bacteria as hypothesized by several researchers (Kim et al., 2004; McSwain et al., 2004a; Qin et al., 2004a,b; Wang et al., 2004; Hu et al., 2005; Liu et al., 2005), the aerobic granules were densely packed microbial aggregates and their densities were much higher than that of conventional activated sludge. In addition, the aerobic granules were known to exhibit attributes of:

1) Regular, smooth and nearly round in shape

2) Excellent settleability

3) Dense and strong microbial structure

4) High biomass retention

5) Ability to withstand at high organic loading

6) Tolerance to toxicity

Because of the unique granule attributes, the aerobic granulation technology was recently developed for treating high strength wastewaters containing organics, nitrogen, phosphorus, toxic substances and xenobiotics (Jiang et al., 2002; Moy et al., 2002; Tay et al., 2002b; Lin et al., 2003; Adav et al., 2007a,b,c,d; Adav and Lee, 2008a).
Recent development in aerobic biogranulation technology is now reviewed and presented in this paper. Materials covered by existing reviews are not duplicated herein. Factors affecting granulation, granule characterization, granulation hypotheses, effects of different operational parameters on aerobic granulation, response of aerobic granules to different environmental conditions, their applications in bioremediations, and possible future trends are delineated. Applications in treating municipal and toxic industrial wastewaters as well as useful information on exploring the underlined mechanisms are also highlighted. The review aims at providing understanding on aerobic granulation using newly employed confocal laser scanning microscope (CLSM) techniques and microscopic observations of granules.

\section{Granule formation, characterization, and applications}

Granulation was affected by a number of operational parameters, such as seed sludge, substrate composition, organic loading rate, feeding strategy, reactor design, settling time, exchange ratio, and aeration intensity (hydrodynamic shear force). It seems that there was a relatively small operational "window" for the successful cultivation of aerobic granules. Under favorable conditions, the much desired "super" granules could be formed. Fig. 1 shows the appearance of the acetate-fed granules cultivated using an SBR following 60 days of incubation. A maximum granule size of $2.6 \mathrm{~cm}$ is seen. Some granules exhibited a dark core, indicating the presence of an anaerobic zone within the aerobic granule.

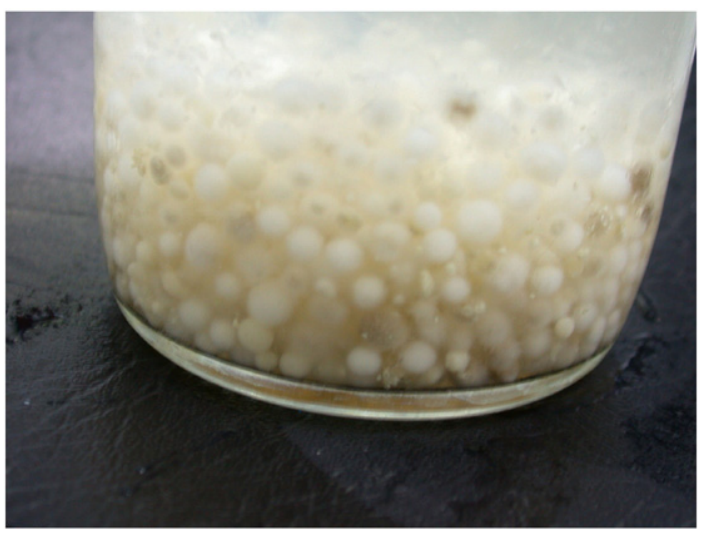

Fig. 1. Appearance of granules cultivated with synthetic substrate containing $1000 \mathrm{mg} \mathrm{L}^{-1}$ acetate and with mineral concentrations that were half of those of Tay et al. (2001a,b). Flowing air for aeration air was supplied at a rate of $2 \mathrm{~cm} \mathrm{~s}^{-1}$. The SBR was operated with 4 min of influent filling, 202 min of aeration, 30 min of settling and 4 min of effluent withdrawal. Incubation time $=60 \mathrm{~d}$. Maximum granule size $=2.6 \mathrm{~cm}$. 


\subsection{Granule formation}

\subsubsection{Seed sludge}

Seed sludge, feed compositions and SBR operational parameters ( $\mathrm{pH}$, temperature, cycling time, and others) affect granulation process (Liu and Tay, 2004). In most studies, aerobic granules were cultivated with activated sludge seed. The bacterial community residing in activated seed sludge was important for aerobic granulation process as the hydrophilic bacteria would be less likely to attach to sludge flocs compared with the hydrophobic counterpart, which constitutes the majority of free bacteria in the effluent from full-scale treatment plants (Zita and Hermansson, 1997). The greater the number of hydrophobic bacteria in the seed sludge the faster the aerobic granulation with excellent settleability (Wilen et al., 2007).

\subsubsection{Feed composition}

Various substrates were used to cultivate aerobic granules, including glucose, acetate, phenol, starch, ethanol, molasses, sucrose and other synthetic wastewater components (Liu and Tay, 2004; Tay et al., 2002a; Tay et al., 2004a; Zheng et al., 2005, Adav et al., 2007a,b,c, $\mathrm{d}, \mathrm{e})$. Information on granule cultivation with real wastewater was also reported (Arrojo et al., 2004; de Bruin et al., 2004; Schwarzenbeck et al., 2005; Su and Yu, 2005, Wang et al., 2007a,b,c). The Cultivation of granules with phenol as a carbon and energy source demonstrated dominance of the Proteobacterium (Jiang et al., 2004b; Whiteley and Bailey 2000; Adav et al., 2007c). Adav and Lee (2008b) cultivated single strain granules from phenol-containing wastewaters.

The positive, divalent and trivalent ions, such as $\mathrm{Ca}^{2+}, \mathrm{Mg}^{2+}, \mathrm{Fe}^{2+}$ and $\mathrm{Fe}^{3+}$ could bind to negatively charged cells to form microbial nuclei (Mahoney et al., 1987). Jiang et al. (2003) revealed that the addition of $\mathrm{Ca}^{2+}$ ions accelerated aerobic granulation. Granules were formed in 16 days when $100 \mathrm{mg} \mathrm{Ca}^{2+} \mathrm{L}^{-1}$ was added in the feed whereas 32 days were required without the addition of $\mathrm{Ca}^{2+}$.

The $\mathrm{pH}$ of medium significantly affected the microbial growth rate. Oxidation at high OLR produced sufficient $\mathrm{CO}_{2}$ to reduce $\mathrm{pH}$ in unbuffered solutions (McSwain et al., 2004a). Fungi grew well at low $\mathrm{pH}$ and may contribute significantly to the initial granulation (McSwain et al., 2004a; Beun et al., 1999; Williams and de los Reyes, 2006) since they could release protons in exchange for $\mathrm{NH}_{4}^{+}$in the solution (Deacon, 2006), thereby further reducing the $\mathrm{pH}$ in the reactor. Yang et al. (2008) noted that, aerobic granulation at pH 4.0 in the presence of a fungus produced a granule size of about $7 \mathrm{~mm}$, while at $\mathrm{pH} 8.0$ when the granulation was controlled by bacteria the granule size reached only $4.8 \mathrm{~mm}$. Up to now, however, the effects of $\mathrm{pH}$ on the inoculum selection and aerobic granulation have not been fully addressed.

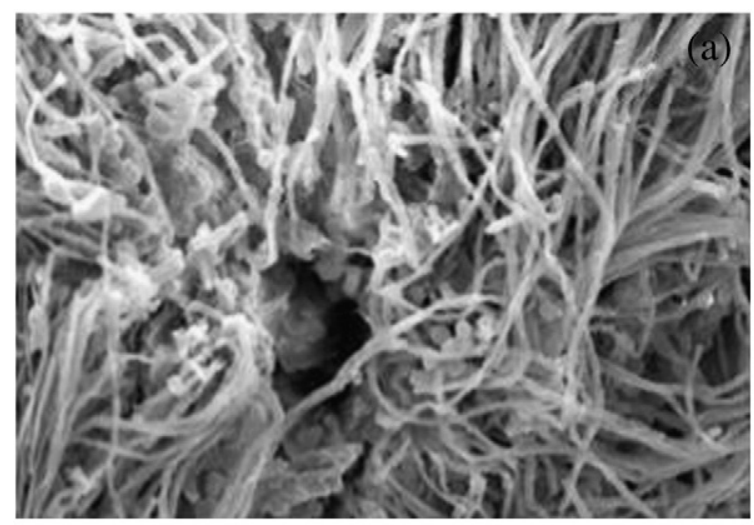

\subsubsection{SBR operation}

It appeared that aerobic granules were successfully cultivated only in SBR. The cyclic operation of SBR consisted of influent filling, aeration, settling and effluent removal. Liu and Tay (2007a) noted that, when cycle time increased from 1.5 to $8 \mathrm{~h}$, the specific biomass growth rate of granular sludge decreased from 0.266 to $0.031 \mathrm{~d}^{-1}$, while the corresponding biomass growth yield $\left(Y_{\text {obs }}\right)$ decreased from 0.316 to $0.063 \mathrm{~g} \mathrm{VSS} \mathrm{g}^{-1}$ COD. Furthermore, the granules cultivated at $1.5 \mathrm{~h}$ cycle time were the biggest in size while the granules cultivated at $4 \mathrm{~h}$ cycle time were the most compact ones compared with those cultivated at other cycle times. Liu and Tay (2007b) noted the existence of optimal starvation time for enhanced granule stability. At

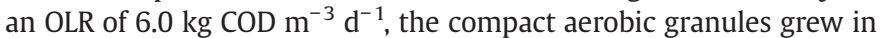
size but gradually lost their stability corresponding with filamentous growth (Zheng et al., 2006).

The aeration period in SBR operation consisted of two phases: a degradation phase in which substrate depleted to a minimum, followed by an aerobic starvation phase in which substrate was no longer available. A long starvation period weakened the granule stability (Wang et al., 2005a, 2006). McSwain et al. (2004b) enhanced aerobic granulation by intermittent feeding. Pulse feeding to the SBR contributed to compact aerobic granules. Although starvation was proposed not to be a prerequisite for aerobic granulation (Liu and Tay, 2008; Liu et al., 2007), increases in hydrophobicity on carbonstarvation had been reported (Sanin et al., 2003; Sanin, 2003; Chen and Strevett, 2003). The impact of feast-famine operation on granulation process was not well understood.

Short settling time caused washout of poorly settled suspended biomass and retained only well settled granules (Qin et al., 2004a,b). Studies have indicated that short settling time could enhance aerobic granulation (Jiang et al., 2002; Lin et al., 2003; Liu et al., 2003a; Yang et al., 2003; McSwain et al., 2004a; Hu et al., 2005).

Adav et al. (2007b) compared the granulation processes in three identical reactors fed with phenol-containing wastewater and aerated at different intensities (1-3 $\mathrm{L}$ air $\left.\mathrm{min}^{-1}\right)$. At low aeration intensity $\left(1 \mathrm{~L} \mathrm{~min}^{-1}\right)$, no granules were formed. At high aeration rate $\left(3 \mathrm{~L} \mathrm{~min}^{-1}\right)$, mature and stable granules $(1-1.5 \mathrm{~mm})$ with a compact interior were formed. At intermediate intensity $\left(2 \mathrm{~L} \mathrm{~min}^{-1}\right)$, large granules (3-3.5 mm) with overgrown filaments were formed (Fig. 2). While Liu and Liu (2006) accounted for the possible causes to filament overgrowth, Adav et al. (2007b) claimed that intermediate aeration could neither yield sufficient oxygen supply nor break down overgrown filaments, hence leading to SBR failure. Restated, strong shear force would not only "compact" aggregates into granules, but also would provide sufficient oxygen to suppress filament growth for a long-term operational stability.

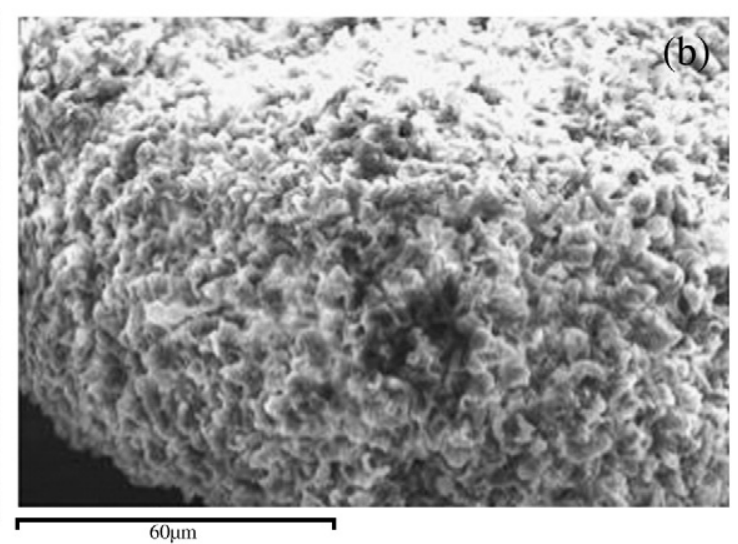

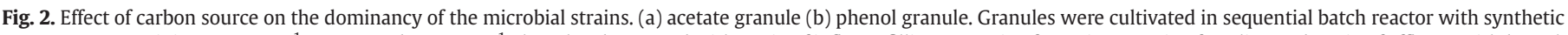

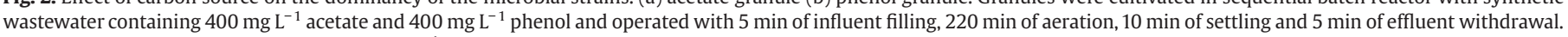
Air for aeration was supplied at a rate of $3 \mathrm{~cm} \mathrm{~s}^{-1}$. 
Keeping the operation at an appropriate solids retentions time (SRT), or the so-called sludge age, was essential to maintain granule stability (Li et al., 2007a). Li et al. (2007b) investigated aerobic granulation in membrane bioreactor, and measured the total extracellular polymeric substances (EPS) contents on day 5 as $39.6 \mathrm{mg} \mathrm{gSS}^{-1}$, and as $749.5 \mathrm{mg} \mathrm{gSS}^{-1}$ on day 28. Nagaoka et al. (1996) had suggested that EPS adsorbed on the surface of aerobic biogranules led to increased water content and loose-structure of biogranules.

Most aerobic granular sludge research was carried out at room temperature $\left(20-25{ }^{\circ} \mathrm{C}\right)$. The SBR operation at $8{ }^{\circ} \mathrm{C}$ yielded granules, which were irregular in shape and with outgrowth of filamentous organisms that caused severe biomass washout and unstable operation (de Kreuk et al., 2005b). The corresponding denitrifying capacity and nutrient removal rate of the granules were also poor (de Kreuk et al., 2005b). Aerobic granulation at low temperatures was not possible with the present understanding.

\subsection{Granule characterization}

A large number of parameters were investigated to study characteristics of aerobic granules. These parameters include physical (settling velocity, density, specific gravity (SG), sludge volume index (SVI)), chemical (specific oxygen utilization rate (SOUR), EPS), and biological parameters. General characteristics of sludge granules, such as size, structure, settling performance, stability against shear forces, EPS content, reactor performance, and metabolism rates were reported in research works (de Kreuk et al., 2005a; Etterer and Wilderer 2001; Hulshoff Pol et al., 2004; Inizan et al., 2005; McSwain et al., 2004a; Moy et al., 2002; Tay et al., 2003).

\subsubsection{Physical parameters}

Settling velocity of granules determined the efficiency of solidliquid separation which was a critical parameter for wastewater symptoms. The settling velocity varied from 25 to $70 \mathrm{mh}^{-1}$ and was significantly higher than that of sludge floc (7 to $10 \mathrm{mh}^{-1}$ ) (Liu et al., 2003b; Qin et al., 2004b). High settling velocity increased the biomass retention capacity of the reactor and subsequently enhanced the organic degradation capability. Mu and Yu (2006) evaluated the fractal dimensions of granules as an index to characterize the granule morphology. Anuar et al. (2007) discussed the effects of mixing conditions on the settling behavior of aerobic granules. Mu et al. (2008) noted that the drag coefficients of aerobic granules were less those of smooth rigid spheres or of biofilm-covered particles. Adav et al. (2008a) quantitatively evaluated the hydraulic characteristics of aerobic granules using size exclusion chromatography. These authors noted that the intra-granular transport for molecules larger than approximately 140,000 Da can be severely limited by diffusional resistance. On the other hand, Kim et al. (2008) highlighted the possible flaws using settling behavior to characterize the aerobic granules at different COD loading rates.

\subsection{Chemical parameters}

Liu et al. (2003e) correlated the cell surface hydrophobicity and formation of heterotrophic and nitrifying granules. The hydrophobicity of granular sludge was two fold higher than the conventional bioflocs (Liu et al., 2004a). Increase in shear force would increase the cell surface hydrophobicity while cell surface hydrophobicity showed insignificant effects on organic loading rates (Liu et al., 2003e). Detailed mechanisms corresponding to the noted changes remain unclear.

EPS are metabolic products accumulating on the surface of bacterial cells, which could alter the physico-chemical characteristics of cellular surface such as charge, hydrophobicity and other properties. Adav and Lee (in press) extracted EPS from aerobic granules using seven extraction methods (Fig. 3). Since the aerobic granules exhibited a compact interior structure, different extraction methods yielded different extracted quantities of EPS. Adav and Lee (in press) recommended that ultrasound followed by the chemical reagents formamide and $\mathrm{NaOH}$ outperformed other methods in extracting EPS from aerobic granules. The total polysaccharides/total proteins (PS/ PN) ratios ranged between 3.4 and 6.2 for granules, much higher than that for sludge flocs (approximately 0.9 ). The relatively high proteins contents presented an essential feature for cultivated aerobic granules (McSwain et al., 2005).

The excitation-emission matrix (EEM) characterization of EPS demonstrated three major peaks in the spectrum with excitation/ emission (Ex/Em) wavelengths at 220-230/340-350 nm, [peak A] 270-280/340- $350 \mathrm{~nm}$, [peak B] and 330-340/420-430 nm, [peak C] (Fig. 4). Based on the classification scheme developed by Chen et al. (2003), peaks A, B, and C were in regions II (aromatic proteins), IV (soluble microbial by-product-like), and V (humic acid-like), respectively. Sheng and Yu (2006) and Adav et al. (2007b) analyzed shifts in position or change in intensity of EEM peaks as evidence of chemical changes in the extracted EPS.

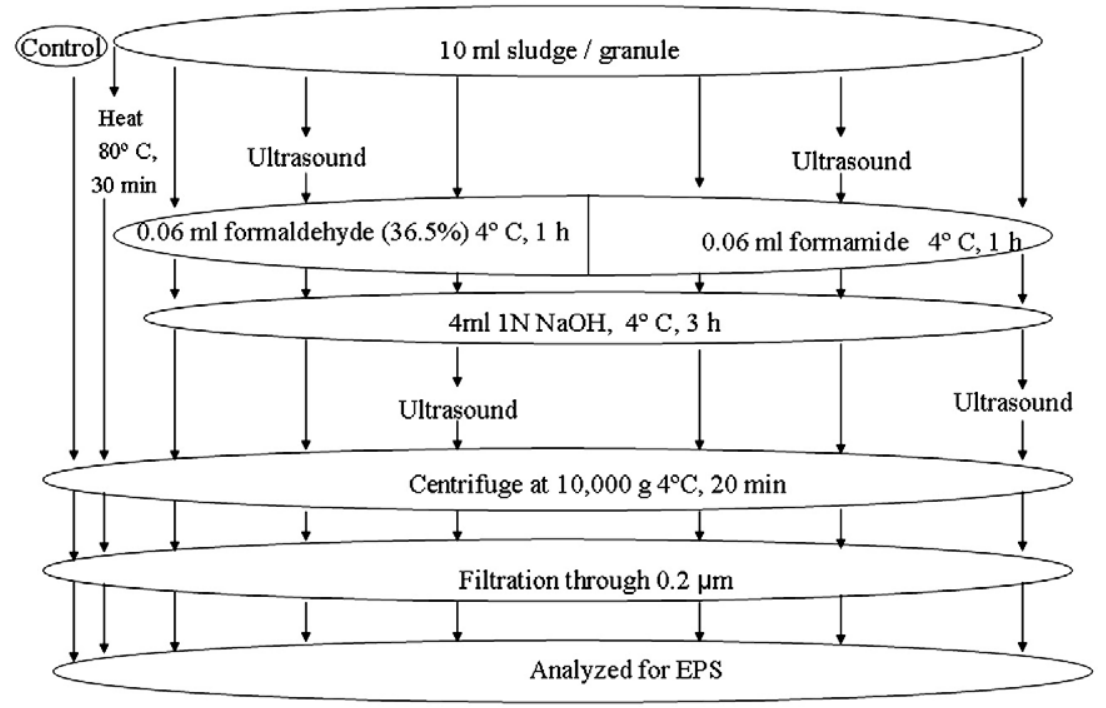

Fig. 3. Flow chart of EPS extraction methods (Adav and Lee, in press). 


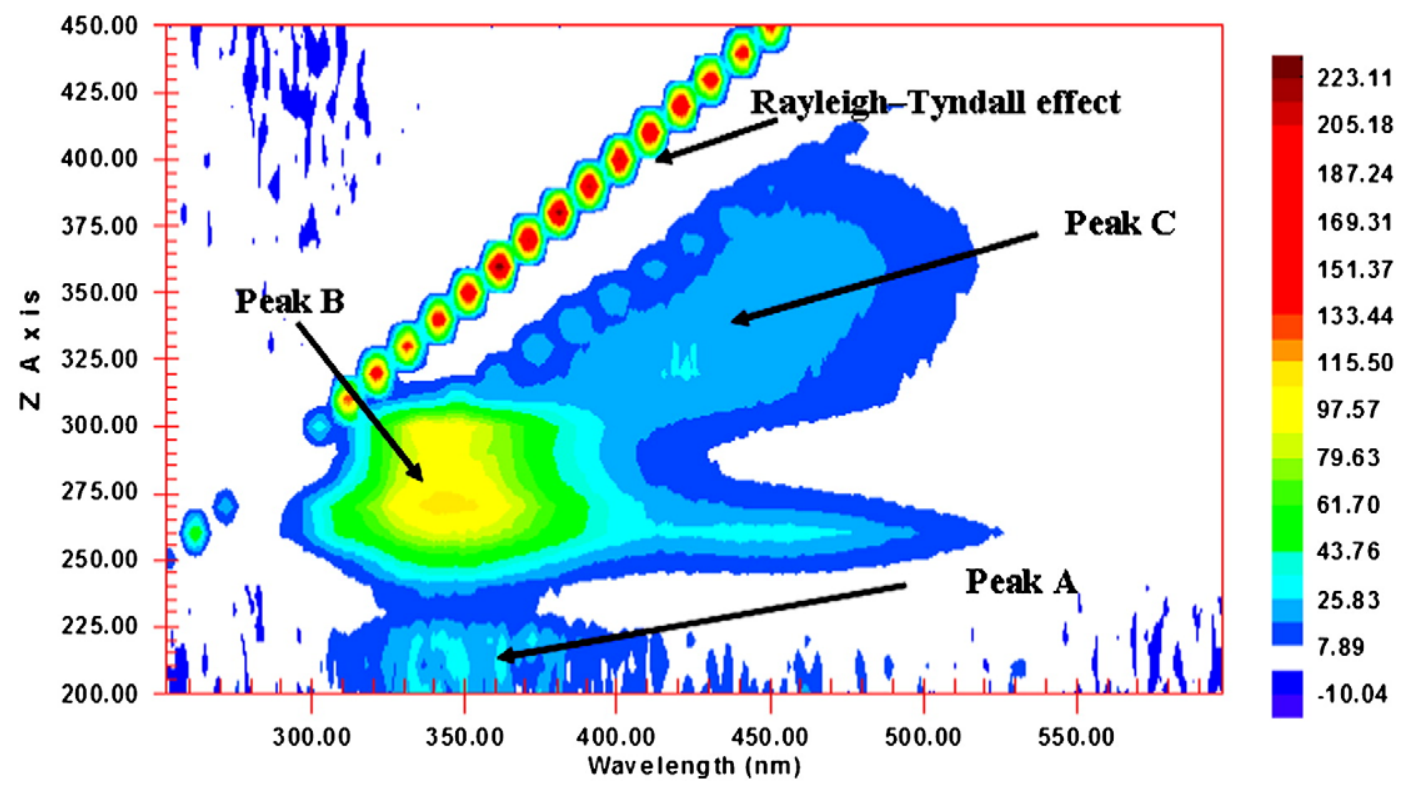

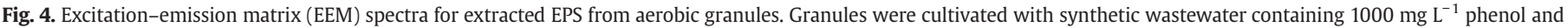

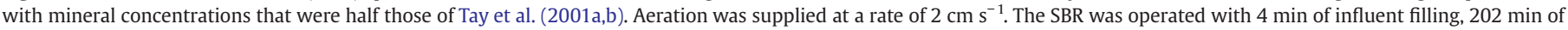
aeration, $30 \mathrm{~min}$ of settling and $4 \mathrm{~min}$ of effluent withdrawal. Incubation time $=20 \mathrm{~d}$. Maximum granule size $=1.2 \mathrm{~mm}$.

\subsubsection{Biological parameters}

Scanning electron microscope (SEM), light microscopy, and CLSM together with fluorescence in situ hybridization (FISH) allowed insights into the microbial structure of the aerobic granules (Yi et al., 2003; Tay et al., 2002c; Jang et al., 2003; Meyer et al., 2003; Tsuneda et al., 2003). Heterotrophic, nitrifying, denitrifying, phosphorousaccumulating bacteria, and glycogen-accumulating bacteria have been identified in aerobic granules developed under different conditions (Jang et al., 2003; Meyer et al., 2003; Tsuneda et al., 2003; Lin et al., 2003; Yang et al., 2003). Microbial diversity of aerobic granules was closely related to the structure of aerobic granules and the composition of culture media in which they were developed. The taxonomic microbial diversity in wastewater treatment plant and phenol-fed aerobic granules showed the dominance of Proteobacteria (Jiang et al., 2004b; Whiteley and Bailey 2000; Snaidr et al., 1997).

Jiang et al. (2004b) identified ten isolates from matured phenol-fed granules of which six had taxonomic affiliations with $\beta$-proteobacteria, three with Actinobacteria and one with $\gamma$-proteobacteria. Whiteley and Bailey (2000) studied the bacterial populations in the specific compartments of an operational industrial phenol remediation system using Proteobacterium group specific probes and found the majority to be $\beta$ - and $\gamma$-proteobacterium. Gram and Neisser stains and FISH analyses showed that most of the filamentous bacteria in aerobic granules cultivated in brewery wastewater belonged to the genus Thiothrix or to Sphaerotilus natans (Weber et al., 2007). FISH-CLSM technique identified that obligate aerobic ammonium-oxidizing bacterium Nitrosomonas spp. was mainly at a depth of 70 to $100 \mu \mathrm{m}$ from the granule surface, while anaerobic bacterium Bacteroides spp. was detected at a depth of 800 to $900 \mu \mathrm{m}$ from the granule surface (Tay et al., 2002c, Adav et al., 2007a,b,c,d,e). Toh et al. (2003) noted a layer of dead microbial cells at a depth of 800 to $1000 \mu \mathrm{m}$. Adav and Lee (2008a) isolated nine strains and revealed the dominance of $\gamma$-Proteobacterium.

\subsection{Granule applications}

An examination of the applications of granules for wastewater treatment showed many advantages: excellent settleability, high and stable rates of metabolism, resilience to shocks and toxins due to the protection by a matrix of EPS, long biomass residence time, biomass immobilization inside the aggregates and the possibility for bioaugmentation. Bioaugmentation can be regarded as an effective tool in the removal of xenobiotics from wastewater (Wuertz et al., 2004; Bathe et al., 2004).

\subsubsection{Treating toxic organic wastewaters}

Aerobic sludge granules have been successfully applied by Moy et al. (2002) for treatment of high strength organic wastewater. When the COD removal efficiencies were stabilized, the potential of aerobic granules to sustain high organic loading rates was examined by a stepwise increase in organic loading from 6 to $15 \mathrm{~kg} \mathrm{COD} \mathrm{m}^{-3} \mathrm{~d}^{-1}$ without compromising granule integrity.

Phenol was considered to be toxic to aquatic species (Brown et al., 1967; Kibret et al., 2000; Chung et al., 2003) and added an odor to drinking and food-processing water (Rittmann and McCarty, 2001). Aerobic granules have been applied to degrade phenol (Jiang et al., 2002, 2004a; Chou et al., 2004; Chou and Huang, 2005; Tay et al., 2005a,b). Tay et al. (2004b) demonstrated that the granules degraded phenol at a specific rate exceeding $1 \mathrm{~g}$ phenol g${ }^{-1} \mathrm{VSS} \mathrm{d}^{-1}$ at $500 \mathrm{mg} \mathrm{L}^{-1}$ of phenol, or at a reduced rate of $0.53 \mathrm{~g}$ phenol g-1 $\mathrm{VSS} \mathrm{d}^{-1}$ at $1900 \mathrm{mg} \mathrm{L}^{-1}$ of phenol. Adav et al. (2007a) reported that aerobic granules could degrade phenol at $1.18 \mathrm{~g}$ phenol g ${ }^{-1} \mathrm{VSS} \mathrm{d}^{-1}$. One likely reason that accounted for the high degradation efficiency of granules that degrade phenol was the mass transfer barrier provided by a granule matrix that produced lower local phenol concentrations on cells than the bulk value (Liu and Tay, 2004).

Pyridine and its derivatives are by-products of coal gasification (Stuermer et al., 1982) and retorting oil shale (Leenheer et al., 1982), and were utilized as a catalyst in the pharmaceutical industry. Aerobic granules could efficiently degrade pyridine over initial concentrations of $200-2500 \mathrm{mg} \mathrm{L}^{-1}$ (Adav et al., 2007a). At initial pyridine concentrations of 250 and $500 \mathrm{mg} \mathrm{L}^{-1}$, degradation kinetics followed closely a zero-order kinetics with no time delay. The specific degradation rate of pyridine was 73.0 and $66.8 \mathrm{mg}$ pyridine $g \mathrm{VSS}^{-1} \mathrm{~h}^{-1}$ at 250 and $500 \mathrm{mg} \mathrm{L}^{-1}$ of pyridine, respectively.

Phenol degrading granules have the capability of using both phenol and pyridine. Adav et al. (2007a) applied Michaelis-Menten kinetics and Lineweaver-Burk plot to study the behavior of granules in the presence of phenol and pyridine and found competitive type of interactions. The specific enzyme for pyridine degradation was 
present in the system that had a high affinity for phenol. Thus, phenol granules could be applied for the removal of phenol in the presence of pyridine in industrial wastewater.

The sludge granules were tested for removal of toxic organic compounds by Xie (2003). Yi et al. (2006) reported on the biodegradation of $p$-nitrophenol (PNP) by aerobic granules in a SBR. The specific PNP degradation rate increased with corresponding increase in PNP concentration up to $40.1 \mathrm{mg} \mathrm{L}^{-1}$ with a peak at $19.3 \mathrm{mg}$ PNP $g$ of VSS ${ }^{-1} h^{-1}$, and declined with any further increase in PNP concentration as substrate.

Wang et al. (2007b) efficiently treated wastewater containing 2,4dichlorophenol with glucose as a co-substrate. Zhang et al. (2008) noted that the methyl $t$-butyl ether (MTBE) can be efficiently degraded by aerobic granular sludge with ethanol as a co-substrate.

\subsubsection{Treating dairy wastewater}

It was well known that genuine wastewaters exhibited a rather different behavior in biological degradability from that of synthetic wastewaters due to presence of a wide range and different type of organic matters. Synthetic wastewater was used in almost all the studies, but information on the performance of aerobic granules in the treatment of genuine wastewater was rare (de Bruin et al., 2004; de Villiers and Ibala, 2003; Schwarzenbeck et al., 2004b). The dairy wastewater contained significant concentrations of nutrients and hence the removal efficiency in this respect was also of great interest. Schwarzenbeck et al. (2005) used wastewater from dairy plant in investigating the performance of aerobic granules for dairy wastewater treatment. The removal efficiencies of $90 \%$ of total COD, $80 \%$ of total $\mathrm{N}$ and $67 \%$ of total $\mathrm{P}$ were reported at a volumetric exchange ratio of $50 \%$.

\subsubsection{Removal of nitrogen and phosphorus}

Complete nitrogen removal involves nitrification and denitrification. Nitrite and nitrate produced from nitrification were reduced to gaseous nitrogen by denitrifiers. Yang et al. (2004b) investigated the simultaneous removal of organics and nitrogen by aerobic granules. This was due to the coexistence of heterotrophic, nitrifying, and denitrifying populations in aerobic sludge granules. Similar heterotrophic nitrifying microbial populations in aerobic granules and alternate nitrification and denitrification with nitrification rate up to 97\% and COD removal efficiency of 95\% were reported (Jang et al., 2003). Use of aerobic granules for nitrification and denitrification were also reported by Beun et al. (2001). Dissolved oxygen concentration had a pronounced effect on the efficiency of denitrification by sludge granules.

Mosquera-Corral et al. (2005) revealed the significant role of oxygen on the simultaneous nitrification and denitrification processes. Low oxygen concentration resulted in a low rate of nitrification and a high rate of denitrification. Picioreanu et al. (1998) postulated that the low ratio of biomass growth rate versus diffusive transport resulted in the development of smooth biofilms. If this proposed ratio also determined the structure of the granules, selection for slow growing organisms would lead to stable granular sludge at low oxygen concentrations. Performance of nitrifying granules that had been produced in aerobic upflow fluidized bed (AUFB) reactor in wastewater containing high concentration of ammonia (1000-1400 $\mathrm{g} \mathrm{N} \mathrm{m}^{-3}$ ) had been studied (de Kreuk and Van Loosdrecht, 2004; Tsuneda et al., 2006). de Kreuk et al. (2005b) claimed that simultaneous COD, N, and P removal was possible at low oxygen saturation (20\%), because of heterotrophic growth inside the granules.

Phosphorus-accumulating microbial granules were cultivated at different substrate $\mathrm{P} / \mathrm{COD}$ ratios in the range from $1 / 100$ to $10 / 100$ in SBR by Lin et al. (2003). The granules had characteristic P-accumulating potential with concomitant uptake of soluble organic carbon and release of phosphate in the anaerobic stage, followed by rapid phosphate uptake in the aerobic stage. The accumulated phosphorus showed a decreased trend with the increase in substrate $\mathrm{P} / \mathrm{COD}$ ratio. A range in granule P content between $1.9 \%$ and $9.3 \%$, depending on the ratio of $\mathrm{P} / \mathrm{COD}$ of the influent had been reported. Influent with a $\mathrm{P} / \mathrm{COD}$ ratio of $2.5 \%$ resulted in granules with a P content of nearly $6 \%$. Similar results were noted by Cassidy and Belia (2005) with an influent P/COD ratio of 2.8\%. Removal of COD and P were over $98 \%$, and removal of N and VSS were over $97 \%$ in treating abattoir (slaughterhouse) wastewater with aerobic sludge granules in an SBR were reported by Cassidy and Belia (2005). Thayalakumaran et al. (2003) also reported similar COD, N, P, and VSS removals in an aerobic SBR treating a slaughter house wastewater with flocculating sludge.

The simultaneous nitrification, denitrification and phosphorus removal process was studied in a laboratory-scale SBR by alternate aerobic and anaerobic period for 450 days by Lemaire et al. (2007). Good phosphorus removal and nitrification occurred throughout the SBR with a dominance of Accumulibacter spp. (a polyphosphateaccumulating organism, PAO) and Competibacter spp. (a glycogen non-polyphosphate-accumulating organism, GAO). Accumulibacter spp. was dominant in the outermost $200 \mu \mathrm{m}$ region of the granule while Competibacter spp. dominated in the granule central zone.

\subsubsection{Removal of heavy metals or dyes}

Several biomaterials including marine algae, fungi, activated sludge and digested sludge were used as a biosorbent (Lodi et al., 1998; Taniguchi et al., 2000; Valdman and Leite, 2000). Major adsorbents currently used were in the form of suspended biomass (Liu et al., 2003c,d) but had several drawbacks such as post-separation, stability of biosorbents and regeneration after use. The maximum biosorption capacity of individual copper (II) and zinc (II) by aerobic granules were closely related to the initial concentrations of the copper and zinc in the reactor and were $246.1 \mathrm{mg} \mathrm{g}^{-1}$ and $180 \mathrm{mg} \mathrm{g}^{-1}$ respectively (Xu et al., 2004). These drawbacks of suspended adsorbents were limiting their application for the removal of dyestuffs from industrial wastewater. Aerobic granules played a promising role in adsorption of toxic chemicals due to a high surface area, porosity and good settling capability. The highly toxic heavy metals had been removed with sludge granules by biosorption (Liu et al., 2002, 2003c,d). The removal of the cationic dye, Rhodamine B, by adsorption using aerobic granules was governed by the Langmuir adsorption isotherm (Zheng et al., 2005). The maximum adsorption density of aerobic granules was three times greater than that of sludge flocs.

\subsubsection{Removing particulate matter}

Aerobic granular sludge was successfully cultivated in a SBR treating wastewater from the malting process with a high content of particulate organic matter (Schwarzenbeck et al., 2004a). At an organic loading rate of $3.2 \mathrm{~kg} \mathrm{COD} \mathrm{m}^{-3} \mathrm{~d}^{-1}$ and an influent particle concentration of $0.95 \mathrm{~g} \mathrm{~L}^{-1} \mathrm{MLSS}$, an average removal of $50 \%$ in total COD and $80 \%$ in soluble COD could be achieved. A comparison of granular and flocculent sludge grown under the same operating conditions showed no significant difference in removal efficiency, although granules exhibited a higher metabolic activity in terms of specific oxygen uptake rate. During the particulate removal by aerobic granulation, two distinct mechanisms were observed: during initial granule formation, particles were incorporated into the biofilm matrix and for mature granules, a high level of protozoa growth on the granule surface accounted for the ability to remove particulate COD.

\subsubsection{Removal of nuclear waste}

The use of aerobically grown granular biomass as novel biomaterials for removing soluble uranium had been demonstrated by Nancharaiah et al. (2006). They studied the biosorption of uranium $[\mathrm{U}(\mathrm{VI})]$ at different initial $\mathrm{pH}$ values (1 to 8 ) and different initial uranium concentrations ( 6 to $750 \mathrm{mg} \mathrm{L}^{-1}$ ) and observed rapid biosorption $(<1 \mathrm{~h})$ in the acidic $\mathrm{pH}$ range (1 to 6 ) compared to that at $\mathrm{pH} 7.0$ or above. Almost complete removal of uranium in the range $6-100 \mathrm{mg} \mathrm{L}^{-1}$ in less than $1 \mathrm{~h}$ 
was reported. The Redlich-Peterson model gave the best fit when the experimental data were analysed using different adsorption isotherm equations. The maximum biosorption capacity of $\mathrm{U}(\mathrm{VI})$ was determined to be $218 \pm 2 \mathrm{mg} \mathrm{g}^{-1}$ dry granular biomass. In Nancharaiah's study, light metal ions such as $\mathrm{Na}^{+}, \mathrm{K}^{+}, \mathrm{Ca}^{2+}$ and $\mathrm{Mg}^{2+}$ were simultaneously expelled from the granules, indicating involvement of an ion-exchange-driven uranium uptake process. Uranium removal from very low strength solutions suggested that granular biomass could find application in the treatment of low-level liquid uranium wastes, whereas other physicochemical methods were, either not suitable or were expensive.

\section{Granulation mechanism}

\subsection{Granulation steps}

Studies have been proposed to examine the mechanisms that may correspond to the granulation processes. Microbial aggregation was a hypothesis in biology that occurred by intra-, inter- and multi-generic cell-to-cell attachment through cell surface receptors such as proteinsaccharide or protein-protein interaction (Kolenbrander 1985, 1999; Palmer et al., 2001). Tay et al. (2001a) recognized that aerobic granulation was a process of microbial self-immobilization without carrier support. Subsequently, Liu and Tay (2002) proposed that the following four steps corresponded to the granulation process:

1. Microbe-to-microbe contact to form aggregates by hydrodynamic, diffusion, gravity and/or thermodynamic forces;

2. Initial attraction to form aggregates by physical (van der Waals, opposite charge, thermodynamic forces), chemical (ionic pairing, triplet ionic pairing, inter-particulate bridging) or biochemical (cell membrane fusion, cell receptor attraction, cell surface dehydration) forces.

3. Microbial forces to form aggregates by biological glue like cellular clustering and secretion of EPS.

4. Hydrodynamic shear force to stabilize the three dimensional structure of the granule.

5. Using CLSM coupled with different specific florochromes, fluorescent microspheres, and oligonucleotide probes, the interior of bioaggregates collected during aerobic granulation process was examined (McSwain et al., 2005, Adav et al., 2007b,c). The CLSM images for seed flocs and the mature granules using the multicolor fluorescent technique recently developed by Chen et al. (2006, 2007a,b) and Yang et al. (2007) are shown (Fig. 5). In brief, the distributions of proteins, lipids, $\alpha$ - and $\beta$-polysaccharide, total cells
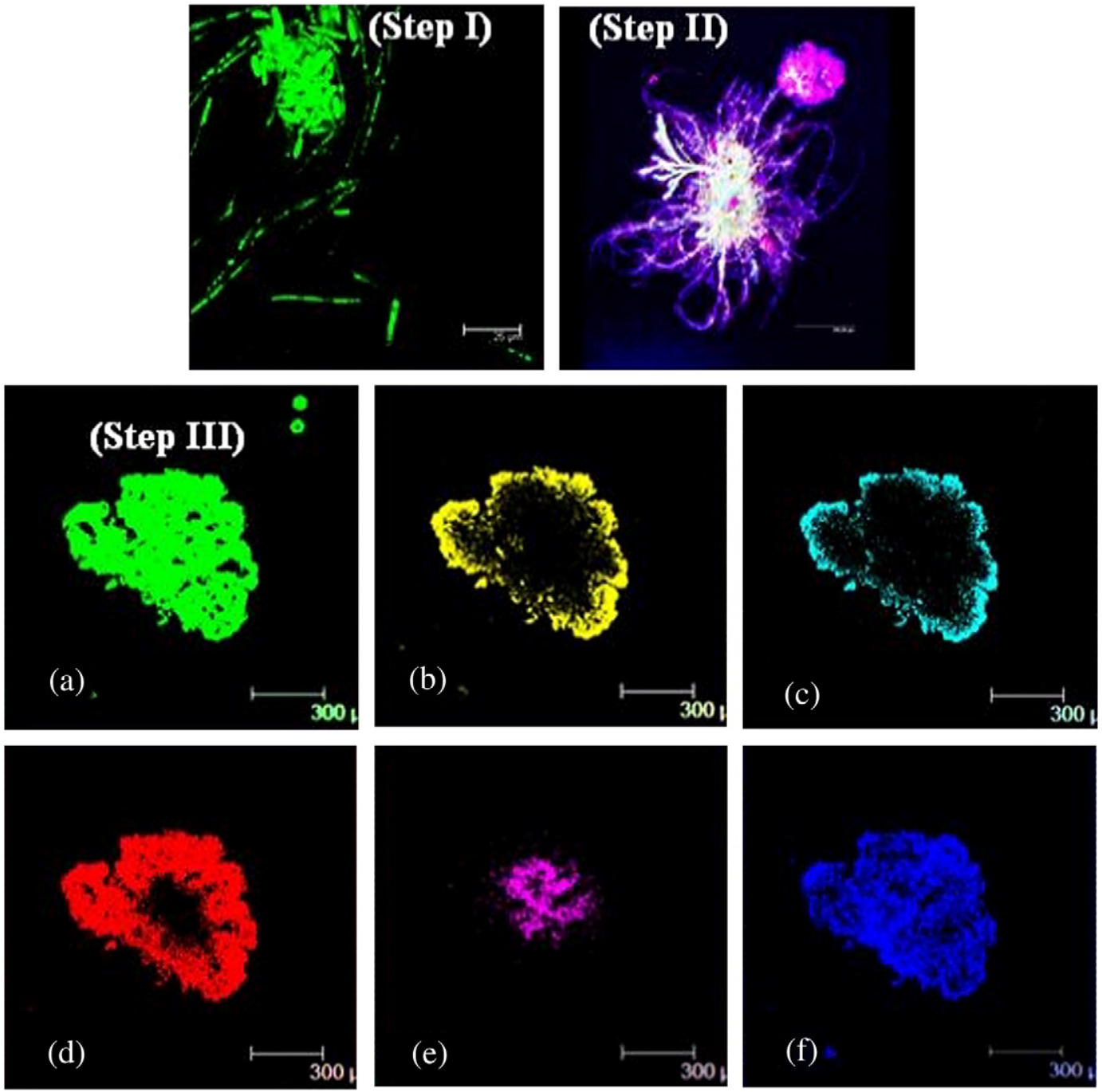

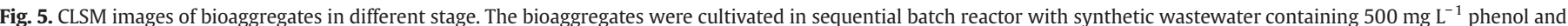

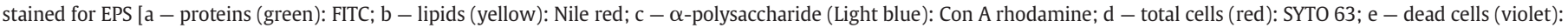

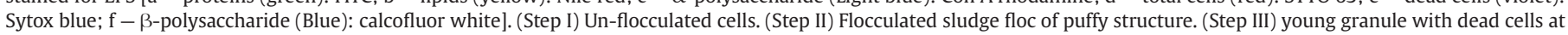
granule core. 
and dead cells were probed in the same bioaggregate. The fluorescent staining and CLSM tests demonstrated that microbial aggregation served as an initial step in granule formation (step II in Fig. 5). The aggregated bacteria secreted EPS at the attachment site, multiplied and grew as large sludge flocs (step III, Fig. 5). The sludge flocs then grew due to proliferation of the attached bacteria and reunion forming granules. This granulation model took into account the noted changes in morphology and interior structure.

\subsection{Selective pressure driven hypothesis}

In SBR operation, only particles that settle within a given time frame could be retained in the reactor, while those with poor settleability were washed out from the system. Apparently, borrowed from biological evolution theory, this physical screening step was considered to provide a "selection pressure" to the biomass in the reactor, and only those which adapted to this challenge (to become big and dense enough to settle fast) would survive and be retained in the reactor (Liu and Tay, 2002). Tay et al. (2002b) studied nitrifying bacterial granulation at different selection pressures and concluded the need of strong selection forces for granulation. The required selection pressures had been created by keeping the constant column height and varying the discharge port height (Wang et al., 2004). Wang et al., (2007c) noted that the stability of the granule could be enhanced with stepwise increased selection pressure.

The physical settling-washing out action was a pure screening step without a demand for the microbes to respond to or to make changes upon the fluid carryout, hence having different intended meaning by the biological evolution theory. Microorganisms in high shear environments adhered by secreting EPS to resist damage of suspended cells by environmental forces (Trinet et al., 1991). Experimental proof was needed to justify how cells communicated with each other and tried to respond to the high liquid upflow in order to become big enough to remain in the reactor. Moreover, those tiny flocs that were washed out initially had no chance to evolve with the environmental changes hence the selection is not fair. Nonetheless, the screening step successfully cultivated aerobic granules in SBR (Beun et al., 2002, Liu et al., 2005).

\subsection{EPS enhanced granulation}

Bacterium secreted sticky material called EPS constituting proteins, polysaccharides, humic acids, and lipids that assisted cell adhesion, thereby should be helpful to initiate the aerobic granulation process (Schmidt and Ahring, 1994; Tay et al., 2001c, Liu et al., 2004b). Accumulation of the secreted EPS correlated with the occurrence of biological adhesion and microbial aggregation (Costerton et al., 1981, Cammarota and Sant'Anna, 1998). Liu et al. (2004a,b) hypothesized that EPS bridged bacterial cells and other particulate matter into an aggregate. High polysaccharide content was noted to facilitate cell-tocell adhesion and strengthen the microbial structure through a polymeric matrix (Costerton et al., 1981; Tay et al., 2001b; Liu et al., 2002). Di Iaconi et al. (2006) noted that hydrodynamic shear compacted the granules but did not affect the EPS content and compositions. On the contrary, metabolic blocking of exopolysaccharide synthesis prevented microbial aggregation (Cammarota and Sant Anna, 1998; Yang et al., 2004b). McSwain et al. (2005) reported high protein content in peptone and glucose-fed aerobic granules with a PN/PS ratio of 6.6-10.9. Adav et al. (2007b) demonstrated that proteins, rather than polysaccharides, were enriched in the sheared granules, which was consistent with the results of McSwain et al. (2005) and Chen et al. (2007a).

The EPS responsible for the structural integrity of aerobic granules has been argued to be non-readily biodegradable to its own producer even in the case of starvation (Sutherland, 1999), while other studies showed that starvation was able to induce the EPS degradation by their own producers that caused bacterial detachment (Zhang and Bishop 2003; Ruijssenaars et al., 2000). Bossier and Verstraete (1996) reported an induction of cell surface hydrophobicity due to starvation; yet a negative effect of starvation on cell surface hydrophobicity had been reported by Castellanos et al. (2000). Conversely, constant cell surface hydrophobicity was observed during carbon starvation (Sanin et al., 2003; Sanin, 2003).

\subsection{Granulation models}

The hypothetical proposal by Liu and Tay's lists most possible forces that corresponded to the granulation process. Mechanistic models on how these forces really work were still largely lacking. A mathematical model developed by $\mathrm{Ni}$ et al. (2007) described the simultaneous autotrophic and heterotrophic growth in granule-based SBRs. Assuming that the autotrophs located at the rim regime and heterotrophs at the core regime, this model predicted that the heterotrophs accounted for most of the oxygen consumption than the autotrophs in the granule. de Kreuk et al. (2007a,b) proposed a mathematical model for an aerobic granular sludge reactor that simultaneously removed COD, nitrogen and phosphate operated at SBR mode. This model particularly described the oxygen penetration depth into the granules, and the ratio of anoxic and aerobic biomass, for overall nutrient removal. Xavier et al. (2007) proposed a multi-scale model of aerobic granular sludge SBR reactor by considering two-dimensional spatial arrangement of four bacterial groups: heterotrophs, ammonium oxidizers, nitrite oxidizers, and phosphate accumulating organisms (PAO). The simulations provided insight into the bioconversion processes with short term dynamics and long reactor operation and integrated dynamics of microbial metabolisms, diffusion reaction with 2-D spatial organization. Ni and Yu (2008) and Ni et al. (2008) demonstrated the storage and growth behavior of denitrifiers in aerobic granules using activated sludge models.

Up to now no proposed models reproduced the entire life for an aerobic granule, from its birth to death, with detailed description of why a layered structure was formed and functioned in organic degradation. Restated, all models treated the substrate degradation, and cell growth and lysis in a simplified framework assuming no cell migration. More works are needed to demonstrate this point.

\section{A closer look}

\subsection{EPS and granule stability}

One of the most serious barriers to practical applications of aerobic granules was the loss of stability of aerobic granules over long-term operation. Two different patterns were noted: granule break-up and filament overgrowth (Liu and Liu, 2006; Adav et al., 2007b, Zhu et al., 2008). For the former, the granules deteriorated into small pieces to flow out with the upflow liquid stream. For the latter, the outgrown filaments produced light and bulky granules for easy washout. Also, the filaments tended to block the pipelines that led to failed reactors. Long-term operation was not possible without stable granules.

An example of the EPS and cell distributions in phenol-fed granule is shown (Fig. 6). The $\beta$-D-glucopyranose polysaccharides formed the core, while the cells and $\alpha$-D-glucopyranose polysaccharides accumulated in the granule outer layers along with lipids. Wang et al. (2005b) applied only one dye, calcofluor white, to their granules and determined that non-soluble $\beta$-polysaccharide formed the outer shell of aerobic granules to provide its strength. Conversely, McSwain et al. (2005) stained their granules using fluorescein-isothiocyanate (FITC), concanavalin A (Con A) lectin conjugates and SYTO 63, to probe the content distribution of proteins, $\alpha$-polysaccharides and cells in the granules. These authors and Zhang et al. (2007) argued that a noncellular protein core in aerobic granule provided its stability. Based on the results by Chen et al. (2007a), the Wang's and McSwain's groups 


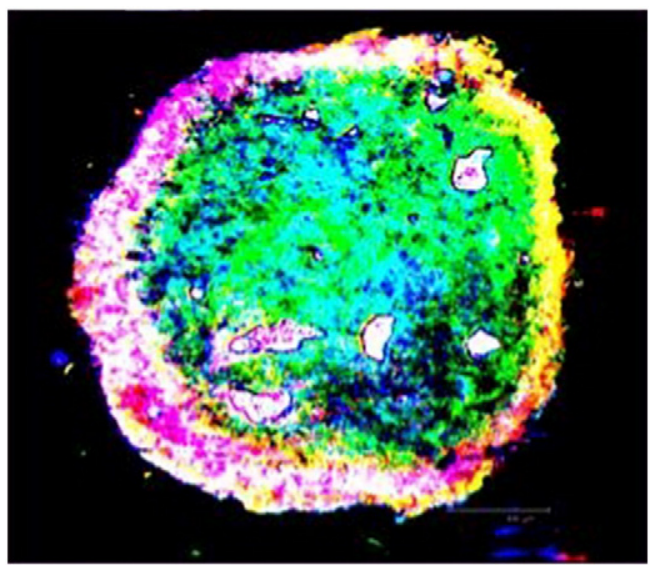

Fig. 6. Phenol granule cultivated in sequential batch reactor with synthetic wastewater containing $250 \mathrm{mg} \mathrm{L}^{-1}$ phenol, stained for all EPS components [proteins (green): FITC; B - lipids (yellow): Nile red; C - total cells (red): SYTO 63; D - dead cells (violet): Sytox blue; $\mathrm{E}-\alpha$-polysaccharide (light blue): Con A rhodamine; $\mathrm{F}-\beta$-polysaccharide (Blue): calcofluor white] and individual images were merged together.

in fact highlighted only part of the whole story (Fig. 6). Staining technique should be used with caution.

Adav et al. (2007d) selectively hydrolyzed proteins, $\alpha-, \beta-$ polysaccharides, and lipids using enzymes and determined the stability change following hydrolysis. These authors noted that, although protein was redundant at the core regime, the selective removal of proteins had minimal impacts on the structural stability of granules. Conversely, hydrolysis of $\beta$-polysaccharides caused granules' disintegration. The updated view was: the granule structure was stabilized by a network principally composed of $\beta$-polysaccharides as the backbone for embedded proteins, lipids, $\alpha$-polysaccharides, and cells. Hence, enrichment of certain (not all) EPS assisted granulation, and enhanced granule stability. Such a conclusion was significant to enhance granule stability during operation and to reduce granule loss in storage.

Storage reduced granule stability (Tay et al., 2002c; Zhu and Wilderer, 2003). Tay et al. (2002c) and $\mathrm{Ng}$ (2002) noted that the granules stored for eight weeks became more irregular and smaller compared to fresh granules and released soluble organic material due to cell hydrolysis. The glucose-fed granules cultivated by Zhu and Wilderer (2003) did not significantly change in size, color, or settleability after storage for seven weeks at room temperatures. Meanwhile, Zhu (2004) claimed that their granules remained stable even after storage for two years in tap water at an ambient temperature $\left(16-26{ }^{\circ} \mathrm{C}\right)$. This result was too good to be realized in practice. Adav et al. (2007f) concluded that phenol-fed aerobic granules could be preserved better than acetate-fed granules at reduced temperatures. Particularly, when stored at sub-freezing temperature $\left(-20^{\circ} \mathrm{C}\right)$, the granules could retain $80-99 \%$ of the initial activity after $48 \mathrm{~h}$ reactivation. Furthermore the addition of phenol in the storing solution significantly preserved the bioactivity of granules at all storage temperatures. Chiu et al. (2007a,b) revealed that the cell core was free of oxygen since the active cell layer, accumulated at the outer rim regime, consumed most intake oxygen. No oxygen was available during long-term storage. Adav et al. (2007f) probed obligate anaerobic Bacteroides sp. over the entire interior of the granules stored at $-20^{\circ} \mathrm{C}$ for $180 \mathrm{~d}$. High storage temperature accompanied with the absence of external substrate yielded endogenous respiration inside the granule. Restated, the EPS core could be "digested" inside out by the anaerobes. Following storage, the protein core presented large "vacuoles" compared with the compact and solid protein core noted for fresh granules.

Low or even freezing temperatures and the presence of toxic substance (phenol) inhibited intra-granular bioactivity, hence assisting in preserving granule stability and cell viability for recovery. Furthermore the phenol-fed granule exhibited a dense $\beta$-polysacchar- ide network in the granule interior, which explained why the latter presented better stability than the former during storage.

\subsection{Intra-granular transport}

Chiu et al. (2006, 2007a,b) probed the DO profiles around and inside a single aerobic granules. With the help of two DO microelectrodes these authors established a DO profiles under transient and steady-state conditions. The external mass transfer coefficient around spherical floc or granule was estimated by the Frossling equation. Chiu et al. (2006) estimated the apparent oxygen diffusivity $\left(D_{\mathrm{app}}\right)$ of acetate-fed and phenol-fed aerobic granules in the range between 1.24 and $2.28 \times 10^{-9} \mathrm{~m}^{2} \mathrm{~s}^{-1}$ of $1.28-2.50 \mathrm{~mm}$ acetate-fed granules, and $2.50-7.65 \times 10^{-10} \mathrm{~m}^{2} \mathrm{~s}^{-1}$ of $0.42-0.78 \mathrm{~mm}$ phenol-fed granules by probing the DO level at the granule center. It was noted that the EPS content significantly affected the intra-granular oxygen diffusivity. The combined multiple staining, CLSM and DO by microelectrode test, demonstrated an active layer of $125 \mu \mathrm{m}$ in thickness that consumed most oxygen in the aerobic granules (Chiu et al., 2007a). The DO tests correlated with the findings by CLSM imaging results. The optimal granular size for treating different wastewaters could be quite different based on the intra-granular transport studies.

\subsection{Strain interactions}

Granules cultivated with inorganic carbon had a dominance of ammonia oxidizing bacteria (AOB) and nitrite oxidizing bacteria (NOB) (Holben et al., 1998; Hao et al., 2002; Jang et al., 2003; Tsuneda et al., 2003; Yang et al., 2004c). When granules were cultivated with acetate or glucose as a carbon source and nitrate as a nitrogen source, the identified bacterial strains were the members of the genus Epistylis, Poterioochromonas, Geotrichum, Geotrichum klebahnii (Williams and de los Reyes, 2006). Yang et al. (2004a,b,c) cultivated aerobic granules with acetate as the sole carbon source and noted that successful granulation could be achieved only when free ammonia concentration was less than $23.5 \mathrm{mg} \mathrm{L}^{-1}$. In addition, an increase in ammonia concentration significantly decreased cell hydrophobicity and affected the EPS production, hence causing failure in granulation. Detailed research work on the mechanisms for ammonium inhibition and on the possible inhibition by other metabolites or chemicals was still not fully understood.

Jiang et al. (2004b, 2006a,b, 2007) isolated ten bacterial strains from aerobic phenol-degrading granules and identified their potential for degrading phenol. The PG-01 strain, a member of $\alpha$-proteobacteria, was common in granules and was the predominant strain in phenol degradation. Another strain affiliated with $\beta$-proteobacteria, PG-08, had minimal phenol degradation capability, and a high propensity for self-aggregation. Hence, different strains on aerobic granules may have specific roles in granule structural integrity and phenol degradation. Yeast genera, such as Rodotorula, Trichosporon, and Candida could degrade high levels of phenol or phenolic compounds (Neujahr, 1990; Kurtz and Crow, 1997; Chang et al., 1998; Ruiz-Ordaz et al., 2000; Chen et al., 2002; Alexievaa et al., 2004; Margesin et al., 2005). Jiang et al. (2005) isolated a Candida tropicalis strain from activated sludge, and identified the growth kinetics and phenol-specific degradation rates for this strain with phenol concentrations of 100 $2000 \mathrm{mg} \mathrm{L}^{-1}$. Adav et al. (2007a) isolated the yeast strain, C. tropicalis from their phenol-degrading granules and reported it as a functionally dominant strain in the phenol degrading granules. Heinaru et al. (2000) isolated 39 bacterial strains from polluted river water (38 Pseudomonas spp. and 1 Acinetobacter sp.) and found from the taxonomic analysis of all the strains reported for phenol biodegradation, more than $70 \%$ strains belong to Proteobacterium phyla.

Adav and Lee (2008b) cultivated granules with a single strain, Acinetobacter calcoaceticus, which exhibited a high autoaggregation potential with interconnecting fibrils (Fig. 7). Seed sludge with 

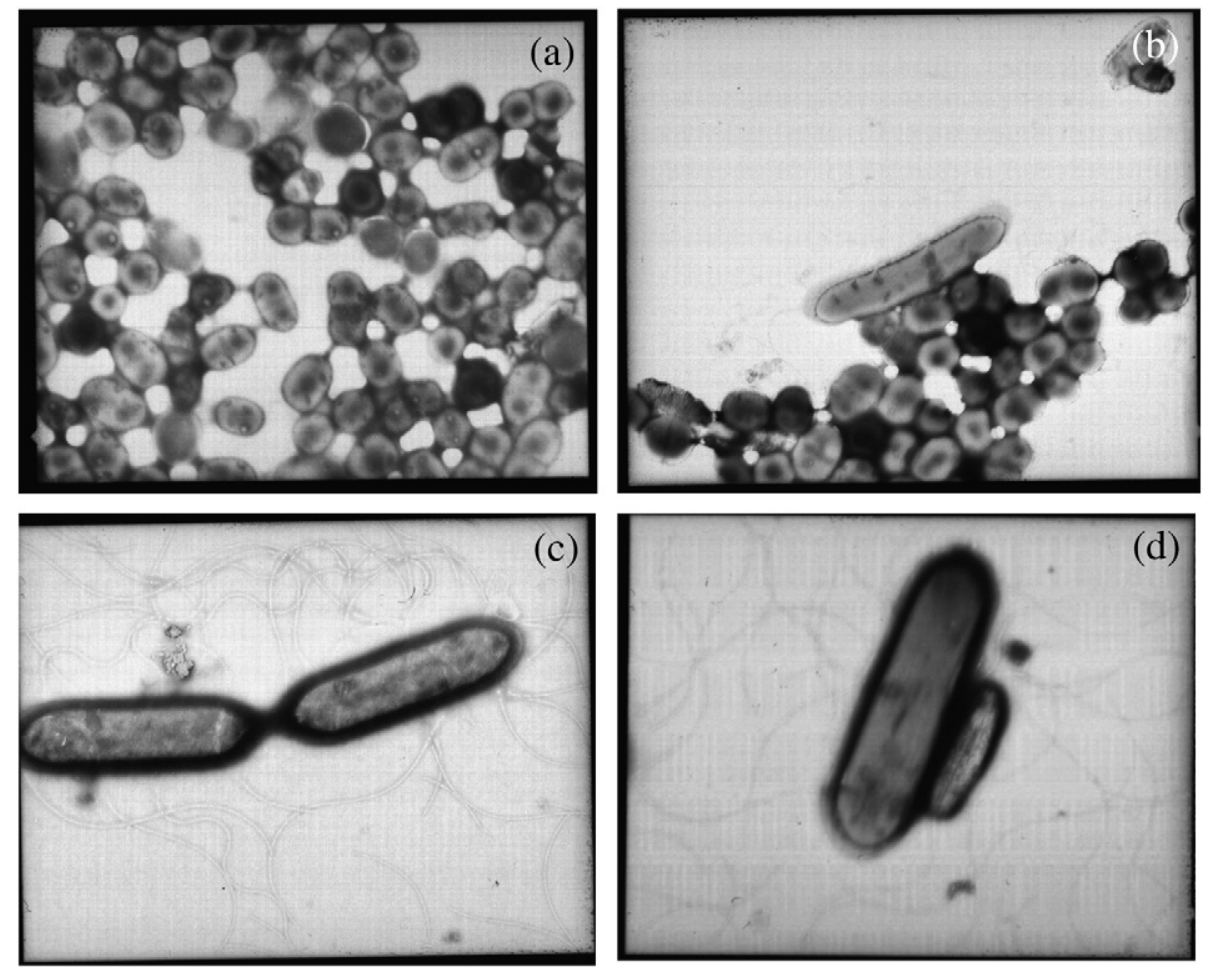

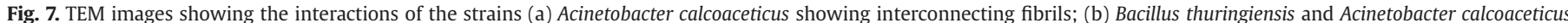
aggregation; (b) Bacillus thuringiensis with flagellum; (d) Bacillus sphaericus with flagella.

enriched Acinetobacter strains could form the granules faster than the sludge dominated by non-flocculating microbial strain. The autoaggregating bacterial strains enhanced the granulation process (Adav and Lee, 2008b, Jiang et al., 2006a,b). The single-culture granules cultivated with $A$. calcoaceticus degraded phenol at a rate of $993.6 \mathrm{mg} \mathrm{g}^{-1} \mathrm{VSS} \mathrm{d}^{-1}$, significantly higher than that of activated sludge and of other aerobic granular sludge (Tay et al., 2005a; Watanabe et al., 1996). The different process performances noted with the mixed-culture granules revealed the difficulty in precise control of the dominant strains in the granules, partly because of the presence of inhibiting strains. The single-culture granules could be biologically precise for engineered systems. The strains A. calcoaceticus, Bacillus thuringiensis and Acinetobacter sp. were both phenol degraders and autoaggregators, and were capable of forming granules individually when inoculated separately in a SBR (Adav et al., 2008b). These findings contradicted the previous view that autoaggregation and phenol degradation were mutually exclusive in aerobic granules and proposed "trade off" functional model (Jiang et al., 2004b, 2006a,b). In single culture granule, only one strain existed and the specific phenol degradation rate could be higher than those from multi-strains due to a lack of inhibiting strains, antibacterial substance and growth inhibiting metabolites. The interactions of $C$. tropicalis with $A$. calcoaceticus, $B$. thuringiensis suggested that the strains coaggregated through the cell surface polymers by lectin-saccharide interactions with the adhesin protein on $A$. calcoaceticus and complementary sugar receptors on $B$. thuringiensis and $C$. tropicalis (Adav et al., 2008b). The presence of flagellum on the B. thuringiensis and Bacillus sphaericus helped the nutrient current towards the granules as both these strain were found to locate on the surface of the granules.

\section{Summary and perspectives}

Formation of granules in aerobic conditions has been possible and appears as a promising technique for high strength or highly toxic wastewater treatment. These granular systems allowed, in many cases, a more stable operation, and the treatment of larger loads, removal of multiple toxic pollutants, inferior volumes for the settling systems and production of better quality effluents than any conventional systems. The formation mechanisms and applications and certain recent efforts to explore this technology in depth has been presented. We also propose the following perspectives to the potential development of the aerobic granular sludge technology in the future.

\subsection{Thermophilic aerobic granules}

The literature regarding aerobic thermophilic applications was reviewed by LaPara and Alleman (1999) and Guven (2004). Studies have been conducted on thermophilic aerobic granular processes which have shown advantages over others including low waste biomass production, higher degradation rates and reduced aeration basin volume (Eckenfelder and Musterman, 1995), elimination of cooling requirements for high temperature wastes (Tripathi, 1999), enhanced solubility and degradation of low-solubility substrate (Becker et al., 1999), and rapid inactivation of pathogens (LaPara and Alleman, 1999). Thermophilic aerobic processes could support autothermal operation or treatment of hot wastes from industries such as pulp and paper production (Barr et al., 1996; Tripathi and Allen, 1999; Jahren et al., 2002) and potato processing (Malladi and Ingham 1993). Operation of an SBR for cultivation of aerobic granules dominated by thermophilic microbial strain may be highly advantageous and competitive due to lower sludge production and pathogenic microbial strains. At present, aerobic granulation system uses activated sludge that contains many pathogenic microbial strains. Therefore, aerobic granules without pathogenic microbial strain are needed for environmental and public health. This developing technology can assist in reducing contamination of receiving groundwater and drinking water in pharmaceuticals and health care sectors. 


\subsection{Combined processes}

Granular bioreactors were able to couple with other treatment units to complement benefits from both processes. For instance, Tay et al. (2008) proposed a new process, named aerobic granular sludge membrane bioreactor (AGSBR) that combined membrane bioreactor (MBR) and aerobic granule technology for wastewater treatment. The system indicated excellent membrane permeability with aerobic granules in a four month operation compared with the conventional $\mathrm{MBR}$, and it was claimed that low membrane fouling was induced by the high strength of the aerobic granules in the surface cake. Jun et al. (2007) also noted enhanced filterability for aerobic granular membrane over conventional biofloc systems. These authors concluded that the main components for fouling were proteins and polysaccharides in the water. The aerobic granular process has great potential to work with anaerobic processes, pre-treatment/RO processes, and others for utilizing its advantage of high biomass retention and tolerance to toxicity from substrates.

\subsection{Cultivation of aerobic granules with genetically engineered microbial species}

The genes enabling degradation of environmental pollutants could be cloned into different bacteria. Many of the bacteria used to supply the genes were actually discovered at hazardous waste sites, after naturally evolving to cope with the hazardous chemicals present. A genetically engineered bacterium that could reduce the concentration of trichloroethylene by a thousand times has been reported by Winter et al. (1989). Genetically engineered bacterium with multiple required genes could serve the purpose of removing multiple toxicants by single transformed bacterium. This area of work was new and has greater potential to be explored into further.

\section{References}

Adav SS, Lee DJ. Physiological characterization and interactions of isolates in phenol degrading aerobic granules. Appl Microbiol Biotechnol 2008a;78:899-905.

Adav SS, Lee DJ. Single-culture aerobic granules with Acinetobacter calcoaceticus. Appl Microbiol Biotechnol 2008b;78:551-7.

Adav SS, Chen MY, Lee DJ, Ren NQ. Degradation of phenol by aerobic granules and isolated yeast Candida tropicalis. Biotechnol Bioeng 2007a;96:844-52.

Adav SS, Lee DJ, Lai JY. Effects of aeration intensity on formation of phenol-fed aerobic granules and extracellular polymeric substances. Appl Microbiol Biotechnol 2007b;77:175-82.

Adav SS, Lee DJ, Ren NQ. Biodegradation of pyridine using aerobic granules in the presence of phenol. Water Res 2007c;41:2903-10.

Adav SS, Lee DJ, Tay JH. Extracellular polymeric substances and structural stability of aerobic granule. Water Res 2007d. doi:10.1016/j.watres.2007.10.013.

Adav SS, Chen MY, Lee DJ, Ren NQ. Degradation of phenol by Acinetobactor strain isolated from aerobic granules. Chemosphere 2007e;67:1566-72.

Adav SS, Lee DJ, Tay JH. Activity and structure of stored aerobic granules. Environ Technol 2007f;28:1227-35.

Adav SS, Chang $\mathrm{CH}$, Lee DJ. Hydraulic characteristics of aerobic granules using size exclusion chromatography. Biotechnol Bioeng 2008a;99:791-9.

Adav SS, Lee DJ, Lai JY. Intergeneric coaggregation of strains isolated from phenoldegrading aerobic granules. Appl Microbiol Biotechnol 2008b;79:657-661.

Adav SS, Lee DJ. Extraction of extracellular polymeric substances from aerobic granule with compact interior structure. J Hazard Mater in press. doi:10.1016/j.jhazmat. 2007.11.058.

Alexievaa Z, Gerginova M, Zlateva P, Peneva N. Comparison of growth kinetics and phenol metabolizing enzymes of Trichosporon cutaneum R57 and mutants with modified degradation abilities. Enzyme Microb Tech 2004;34:242-7.

Anuar AN, Ujang Z, van Loosdrecht MCM, de Kreuk M. Settling behaviour of aerobic granular sludge. Water Sci Technol 2007;56:55-63.

Arrojo B, Mosquera-Corral A, Garrido JM, Mendez R. Aerobic granulation with industrial wastewater in sequencing batch reactors. Water Res 2004;38:3389-99.

Barr TA, Taylor JM, Duff SJB. Effect of HRT, SRT, and temperature on the performance of activated sludge reactors treating bleached Kraft mill effluent. Water Res 1996;30: 799-710.

Bathe S, Mohan TVK, Wuertz S, Hausner M. Bioaugmentation of a sequencing batch biofilm reactor by horizontal gene transfer. Water Sci Technol 2004;49:337-43.

Becker P, Koster M, Popov MN, Markossian S, Antranikian G, Markl H. The Biodegradation of olive oil and the treatment of lipid-rich wool scouring wastewater under aerobic thermophilic conditions. Water Res 1999;33:653-60.

Beun JJ, Hendriks A, van Loosdrecht MCM, Morgenroth E, Wilderer PA, Heijnen JJ. Aerobic granulation in a sequencing batch reactor. Water Res 1999;33:2283-90.
Beun JJ, Heijnen JJ, van Loosdrecht MCM. N-removal in a granular sludge sequencing batch airlift reactor. Biotechnol Bioeng 2001;75:82-92.

Beun JJ, van Loosdrecht MCM, Heijnen JJ. Aerobic granulation in a sequencing batch airlift reactor. Water Res 2002;36:702-12.

Bossier P, Verstraete W. Triggers for microbial aggregation in activated sludge? Appl Microbiol Biotechnol 1996;145:1-6.

Brown VM, Jordan DHM, Tiller BA. The effect of temperature on the acute toxicity of phenol to rainbow trout in hard water. Water Res 1967;1:587-94.

Cammarota MC, Sant'Anna GL. Metabolic blocking of exopolysaccharides synthesis: effects on microbial adhesion and biofilm accumulation. Biotechnol Lett 1998;20: $1-4$.

Cassidy DP, Belia E. Nitrogen and phosphorus removal from an abattoir wastewater in a SBR with aerobic granular sludge. Water Res 2005;39:4817-23.

Castellanos T, Ascencio F, Bashan Y. Starvation-induced changes in the cell surface of Azospirillum lipoferum. FEMS Microbiol Ecol 2000;33:1-9.

Chang YH, Li CT, Chang MC, Shieh WK. Batch phenol degradation by Candida tropicalis and its fusant. Biotechnol Bioeng 1998;60:391-5.

Chen G, Strevett KA. Impact of carbon and nitrogen conditions on E. coli surface thermodynamics. Colloids Surf B: Biointerfaces 2003;28:135-46.

Chen KC, Lin YH, Chen WH, Liu YC. Degradation of phenol by PAA-immobilized Candida tropicalis. Enzyme Microb Technol 2002;31:490-4997.

Chen W, Westerhoff P, Leenheer JA, Booksh K. Fluorescence excitation-emission matrix regional integration to quantify spectra for dissolved organic matter. Environ Sci Technol 2003;37:5701-10.

Chen MY, Lee DJ, Yang Z, Peng XF. Fluorescent staining for study of extracellular polymeric substances in membrane biofouling layers. Environ Sci Technol 2006;40: 6642-6.

Chen MY, Lee DJ, Tay JH. Distribution of extracellular polymeric substances in aerobic granules. Appl Microbiol Biotechnol 2007a;73:1463-9.

Chen MY, Lee DJ, Tay JH. Staining of extracellular polymeric substances and cells in bioaggregates. Appl Microbiol Biotechnol 2007b;75:467-74.

Chiu ZC, Chen MY, Lee DJ, Tay STL, Tay JH, Show KY. Diffusivity of oxygen in aerobic granules. Biotechnol Bioeng 2006;94:505-13.

Chiu ZC, Chen MY, Lee DJ, Wang CH, Lai JY. Oxygen diffusion and consumption in active aerobic granules of heterogeneous structure. Appl Microbiol Biotechnol 2007a;75: 685-91.

Chiu ZC, Chen MY, Lee DJ, Wang CH, Lai JY. Oxygen diffusion in active layer of aerobic granule with step change in surrounding oxygen levels. Water Res 2007b;41: 884-92.

Chou HH, Huang JS. Comparative granule characteristics and biokinetics of sucrose-fed and phenol-fed UASB reactors. Chemosphere 2005;59:107-16.

Chou HH, Huang JS, Hong WF. Temperature dependency of granule characteristics and kinetic behavior in UASB reactors. J Chem Technol Biotechnol 2004;79:797-808.

Chung TP, Tseng HY, Juang RS. Mass transfer effect and intermediate detection for phenol degradation in immobilized Pseudomonas putida systems. Process Biochem 2003:38:1497-507.

Costerton JW, Irvin RT, Cheng KJ. The bacterial glycocalyx in nature and disease. Annu Rev Microbiol 1981;35:299-224.

Dangcong P, Bernet N, Delgenes JP, Moletta R. Aerobic granular sludge - a case report. Water Res 1999;33:890-3.

de Bruin LMM, Kreuk MK, de Roest HFR, van der Uijterlinde C, van Loosdrecht MCM. Aerobic granular sludge technology: alternative for activated sludge? Water Sci Technol 2004;49:1-7.

de Kreuk MK, van Loosdrecht MCM. Selection of slow growing organisms as a means for improving aerobic granular sludge stability. Water Sci Technol 2004;49:9-17.

de Kreuk MK, Pronk M, van Loosdrecht MCM. Formation of aerobic granules and conversion processes in an aerobic granular sludge reactor at moderate and low temperatures. Water Res 2005a;39:4476-84.

de Kreuk MK, Heijnen JJ, van Loosdrecht MCM. Simultaneous COD, nitrogen, and phosphate removal by aerobic granular sludge. Biotechnol Bioeng 2005b;90:761-9.

de Kreuk MK, Picioreanu C, Hosseini M, Xavier JB, van Loosdrecht MCM. Kinetic model of a granular sludge SBR: influences on nutrient removal. Biotechnol Bioeng 2007a;97: 801-15.

de Kreuk MK, Kishida N, van Loosdrecht MCM. Aerobic granular sludge - state of the art. Water Sci Technol 2007b;55:75-81.

de Villiers GH, Ibala HM. Aerobic granulation in a sequencing batch reactor with a petrochemical effluent as substrate. In: IWA, editor. Water, a key to sustainable development in Africa. IWA: Cape Town; 2003.

Deacon J. Fungal biology. 4th ed. MA, USA: Blackwell Publishing; 2006.

Di Iaconi C, Ramadori R, Lopez A, Passino R. Influence of hydrodynamic shear forces on properties of granular biomass in a sequencing batch biofilter reactor. Biochem Eng J 2006;30:152-7.

Eckenfelder WW, Musterman JL. Activated Sludge Treatment of Industrial Wastewater. Lancaster, PA: Technomic Publishing Company; 1995. p. 113.

Etterer T, Wilderer PA. Generation and properties of aerobic granular sludge. Water Sci Technol 2001;43:19-26.

Guven, E. Granulation in thermophilic aerobic wastewater treatment. Ph. D. Dissertation, Marquette University, Milwaukee, WI. 2004

Hao XD, van Loosdrecht MCM, Heijnen JJ. Model-based evaluation of kinetic, biofilm and process parameters in a one-reactor ammonium removal (CANON) process. Biotechnol. Bioeng 2002;77:266-77.

Heinaru E, Truu J, Stottmeister U, Heinaru A. Three types of phenol and p-cresol catabolism in phenol- and p-cresol-degrading bacteria isolated from river water continuously polluted with phenolic compounds. FEMS Microbiol Ecol 2000;31:195-05.

Heijnen J.J., van Loosdrecht M.C.M. Method for acquiring grain-shaped growth of a microorganism in a reactor. European patent EP0826639, 1998. 
Holben WE, Noto K, Sumino T, Suwa Y. Molecular analysis of bacterial communities in a three-compartment granular activated sludge system indicates community-level control by incompatible nitrification processes. Appl Environ Microbiol 1998;64: 2528-32.

Hu L, Wang J, Wen X, Qian Y. The formation and characteristics of aerobic granules in sequencing batch reactor (SBR) by seeding anaerobic granules. Process Biochem 2005;40:5-11.

Hulshoff Pol LW, de Castro Lopes SI, Lettinga G, Lens PNL. Anaerobic sludge granulation. Water Res 2004;38:1376-89.

Inizan M, Freval A, Cigana J, Meinhold J. Aerobic granulation in a sequencing batch reactor (SBR) for industrial wastewater treatment. Water Sci Technol 2005;52: 335-43.

Jahren SJ, Rintala JA, Odegaard H. Aerobic moving bed biofilm reactor treating thermomechanical pulping whitewater under thermophilic conditions. Water Res 2002;36:1067-75.

Jang A, Yoon YH, Kim IS, Kim KS, Bishop PL. Characterization and evaluation of aerobic granules in sequencing batch reactor. J Biotechnol 2003;105:71-82.

Jiang HL, Tay JH, Tay STL. Aggregation of immobilized activated sludge cells into aerobically grown microbial granules for the aerobic biodegradation of phenol. Lett Appl Microbiol 2002;35:439-45.

Jiang HL, Tay JH, Liu Y, Tay STL. $\mathrm{Ca}^{2+}$ augmentation for enhancement of aerobically grown microbial granules in sludge blanket reactors. Biotechnol Lett 2003;25:95.

Jiang HL, Tay JH, Tay STL. Changes in structure, activity and metabolism of aerobic granules as a microbial response to high phenol loading. Appl Microbiol Biotechnol 2004a;63:602-8.

Jiang HL, Tay JH, Maszenan AM, Tay STL. Bacterial diversity and function of aerobic granules engineered in a sequencing batch reactor for phenol degradation. Appl Environ Microbiol 2004b;70:6767-75.

Jiang Y, Wen JP, Li HM, Yang SL, Hu ZD. The biodegradation of phenol at high initial concentration by the yeast Candida tropicalis. Biochem Eng J 2005;24:243-7.

Jiang HL, Tay JH, Maszenan AM, Tay STL. Enhanced phenol biodegradation and aerobic granulation by two coaggregating bacterial strains. Environ Sci Technol 2006a;40: 6137-42.

Jiang HL, Tay STL, Maszenan AM, Tay JH. Physiological traits of bacterial strains isolated from phenol-degrading aerobic granules. FEMS Microbiol Ecol 2006b;57:182-91.

Jiang HL, Maszenan AM, Tay JH. Bioaugmentation and coexistence of two functionally similar bacterial strains in aerobic granules. Appl Microbiol Biotechnol 2007;75: 1191-200.

Jun A, Yang FL, Meng FG, Peng A, Di W. Comparison of membrane fouling during shortterm filtration of aerobic granular sludge and activated sludge. J Environ Sci-China 2007:19:1281-6.

Kibret M, Somitsch W, Robra KH. Characterization of a phenol degrading mixed population by enzyme assay. Water Res 2000;4:1127-234.

Kim SH, Choi HC, Kim IS. Enhanced aerobic floc-like granulation and nitrogen removal in a sequencing batch reactor by selection of settling velocity. Water Sci Technol 2004;50:157-62.

Kim IS, Kim SM, Jang A. Characterization of aerobic granules by microbial density at different COD loading rates. Bioresource Technol 2008;99:18-25.

Kolenbrander PE, Andersen RN, Holdeman LV. Coaggregation of oral bacteroides species with other bacteria: central role in coaggregation bridges and competitions. Infection Immunol 1985;48:741-6.

Kolenbrander PE, Andersen RN, Clemans DL, Whittaker CJ, Klier CM. Potential role of functionally similar coaggregation mediators in bacterial succession. In: Newman HN, Wilson M, editors. Dental plaque revisited: oral biofilms in health and disease Bioline, Cardiff, United Kingdom; 1999. p. 171-86.

Kurtz AM, Crow SA. Transformation of chlororesorcinol by the hydrocarbonoclastic yeasts Candida maltosa, Candida tropicalis, and Trichosporon oivide. Curr Microbiol 1997;35:165-8.

LaPara TM, Alleman JE. Thermophilic aerobic biological wastewater treatment. Water Res 1999;33:895-08

Leenheer JA, Noyes TI, Stuber HA. Determination of polar organic solutes in oil-shale retort water. Environ Sci Technol 1982:16:714-23.

Lemaire R, Yuan Z, Blackall LL, Crocetti GR. Microbial distribution of Accumulibacter spp. and Competibacter spp. in aerobic granules from a lab-scale biological nutrient removal system. Environ Micrbiol 2007. doi:10.1111/j.1462-2920.2007.01456.x.

Lettinga G, van Velsen AFM, Hobma SW, de Zeeuw W, Klapwijk A. Use of the upflow sludge blanket (USB) reactor concept for biological waste water treatment especially for anaerobic treatment. Biotechnol Bioeng 1980;22:699-634.

Li J, Garny K, Neu T, He M, Lindenblatt C, Horn H. Comparison of some characteristics of aerobic granules and sludge flocs from sequencing batch reactors. Water Sci Technol 2007a;55(8-9):403-11

Li X, Li Y, Liu H, Huaa Z, Dua G, Chen J. Characteristics of aerobic biogranules from membrane bioreactor system. J Membr Sci 2007b;287:294-9.

Lin YM, Liu Y, Tay JH. Development and characteristics of phosphorous-accumulating granules in sequencing batch reactor. Appl Microbiol Biotechnol 2003;62:430-5.

Liu Y, Tay JH. The essential role of hydrodynamic shear force in the formation of biofilm and granular sludge. Water Res 2002;36:1653-65.

Liu Y, Tay JH. State of the art of biogranulation technology for wastewater treatment. Biotechnol Adv 2004;22:533-63.

Liu Y, Liu QS. Causes and control of filamentous growth in aerobic granular sludge sequencing batch reactors. Biotechnol Adv 2006;24:115-27.

Liu YQ Tay JH. Influence of cycle time on kinetic behaviors of steady-state aerobic granules in sequencing batch reactors. Enzyme Microb Technol 2007a;41:516-22.

Liu YQ Tay JH. Characteristics and stability of aerobic granules cultivated with different starvation time. Appl Microbiol Biotechnol 2007b;75:205-10.

Liu YQ Tay JH. Influence of starvation time on formation and stability of aerobic granules in sequencing batch reactors. Bioresource Technol 2008;99:980-5.
Liu Y, Yang SF, Tan SF, Lin YM, Tay JH. Aerobic granules: a novel zinc biosorbent. Lett Appl Microbiol 2002;35:548-51.

Liu QS, Tay JH, Liu Y. Substrate concentration-independent aerobic granulation in sequential aerobic sludge blanket reactor. Environ Technol 2003a;24:1235-43.

Liu Y, Lin YM, Yang SF, Tay JH. A balanced model for biofilms developed at different growth and detachment forces. Process Biochem 2003b;38:1761-5.

Liu Y, Xu H, Yang SF, Tay JH. A general model for biosorption of $\mathrm{Cd} 2+\mathrm{Cu} 2+$ and $\mathrm{Zn} 2+$ by aerobic granules. J Biotechnol 2003c;102:233-9.

Liu Y, Yang SF, Xu H, Woon KH, Lin YM, Tay JH. Biosorption kinetics of cadmium (II) on aerobic granular sludge. Process Biochem 2003d;38:995-9.

Liu Y, Yang SF, Liu QS, Tay JH. The role of cell hydrophobicity in the formation of aerobic granules. Curr Microbiol 2003e;46:270-4.

Liu Y, Yang SY, Tay JH, Liu QS, Qin L, Li Y. Cell hydrophobicity is a triggering force of biogranulation. Enzyme Microb Technol 2004a;34:371-9.

Liu YQ, Liu Y, Tay JH. The effects of extracellular polymeric substances on the formation and stability of biogranules. Appl Microbiol Biotechnol 2004b;65:143-8.

Liu Y, Wang ZW, Qin L, Liu YQ Tay JH. Selection pressure-driven aerobic granulation in a sequencing batch reactor. Appl Microbiol Biotechnol 2005;67:26-32.

Liu YQ, Wu WW, Tay JH, Wang JL. Starvation is not a prerequisite for the formation of aerobic granules. Appl Microbiol Biotechnol 2007;76:211-6.

Lodi A, Solisoio C, Converti A, Del Borghi M. Cadmium, zinc, copper, silver and chromium (III) removal from wastewaters by Sphaerotilus natans. Bioprocess Eng 1998;19:197-03.

Mahoney EM, Varangu LK, Cairns WL, Kosaric N, Murray RGE. The effect of calcium on microbial aggregation during UASB reactor start-up. Water Sci Technol, 1987;19: 249-60.

Malladi B, Ingham SC. Thermophilic aerobic treatment of potato processing wastewaters. World J Microbiol Biotechnol 1993;9:45-9.

Margesin R, Fonteyne PA, Redl B. Low-temperature biodegradation of high amounts of phenol by Rhodococcus spp. and basidiomycetous yeasts. Res Microbiol 2005;156: 68-75.

Maximova N, Dahl O. Environmental implications of aggregation phenomena: current understanding. Curr Opin Colloid Interface Sci 2006;11:246-66.

McSwain BS, Irvine RL, Wilderer PA. The influence of settling time on the formation of aerobic granules. Water Sci Technol 2004a;50:195-102.

McSwain BS, Irvine RL, Wilderer PA. The effect of intermittent feeding on aerobic granule structure. Water Sci Technol 2004b;49:19-25.

McSwain BS, Irvine RL, Hausner M, Wilderer PA. Composition and distribution of extracellular polymeric substances in aerobic flocs and granular sludge. App Environ Microbiol 2005;71:1051-7.

Meyer RL, Saunders AM, Zeng RJ, Keller J, Blackall LL. Microscale structure and function of anaerobic- aerobic granules containing glycogen accumulating organisms. FEMS Microbiol Ecol 2003;45:253-61.

Morgenroth E, Sherden T, van Loosdrecht MCM, Heijnen JJ, Wilderer PA. Aerobic granular sludge in a sequencing batch reactor. Water Res 1997;31:3191-4.

Mosquera-Corral A, de Kreuk MK, Heijnen JJ, van Loosdrecht MCM. Effects of oxygen concentration on $\mathrm{N}$-removal in an aerobic granular sludge reactor. Water Res 2005;39: 2676-86.

Moy BYP, Tay JH, Toh SK, Liu Y, Tay STL. High organic loading influences the physica characteristics of aerobic sludge granules. Lett Appl Microbiol 2002;34:407-12.

Mu Y, Yu HQ. Rheological and fractal characteristics of granular sludge in an upflow anaerobic reactor. Water Res 2006;40:3596-3502.

Mu Y, Ren TT, Yu HQ. Drag coefficient of porous and permeable microbial granules. Environ Sci Technol 2008;42:1718-23.

Nagaoka H, Ueda S, Miya A. Influence of bacterial extracellular polymers on the membrane separation activated sludge process. Water Sci Technol 1996;34:165.

Nancharaiah YV, Joshi HM, Mohan TVK, Venugopalan VP, Narasimhan SV. Aerobic granular biomass: a novel biomaterial for efficient uranium removal. Curr Sci 2006;91: 503-9.

Neujahr $\mathrm{H}$. Yeast in biodegradation and biodeterioration processes. Bioprocess Techno 1990;5:321-48.

$\mathrm{Ng} \mathrm{PH}$. Storage stability of aerobic granules cultivated in aerobic granular sludge blanket reactor. Final year report of Bachelor of Engineering 2002. Singapore: Nanyang Technological University; 2002.

Ni BJ, Yu HQ. Storage and growth of denitrifiers in aerobic granules: Part I. Model development. Biotechnol Bioeng 2008;99:314-23.

Ni BJ, Yu HQ Sun YJ. Modeling simultaneous autotrophic and heterotrophic growth in aerobic granules. Water Res 2007. doi:10.1016/j.watres.2007.11.010.

Ni BJ, Yu HQ Xie WM. Storage and growth of denitrifiers in aerobic granules: Part II Model calibration and verification. Biotechnol Bioeng 2008;99:324-32.

Palmer RJ, Kazmerzak K, Hansen MC, Kolenbrander PE. Mutualism versus independence: Strategies of mixed-species oral biofilms in vitro using saliva as the sole nutrient source. Infec Immunol 2001;69:5794-04.

Picioreanu C, van Loosdrecht MCM, Heijnen JJ. Mathematical modeling of biofilm structure with a hybrid differential-discrete cellular automaton approach. Biotechnol Bioeng 1998;58:101-16.

Qin L, Tay JH, Liu Y. Selection pressure is a driving force of aerobic granulation in sequencing batch reactors. Process Biochem 2004a;39:579-84.

Qin L, Liu Y, Tay JH. Effect of settling time on aerobic granulation in sequencing batch reactor. Biochem Eng J 2004b;21:47-52.

Rittmann BE, McCarty PL. Environmental Biotechnology: Principles and applications. New York: McGraw-Hill; 2001.

Ruijssenaars HJ, Stingele F, Hartmans S. Biodegradability of food-associated extracellular polysaccharides. Curr Microbiol 2000;40:194-9.

Ruiz-Ordaz N, Juarez-Ramirez C, Castarion-Gonzalez H, Lara-Rodriguez AR, CristianiUrbina EA, Galindez-Mayer J. Aerobic bioprocesses and bioreactors used for phenol 
degradation by free and immobilized yeast cells. In: Pandalai SG, editor. Recent Research Developments in Biotechnology and Bioengineering. Research Signpost Trivandrum. India; 2000. p. 83-94.

Sanin SL. Effect of starvation on resuscitation and the surface characteristics of bacteria. J Environ Sci Health A 2003;38:1517-28.

Sanin SL, Sanin FD, Bryers JD. Effect of starvation on the adhesive properties of xenobiotic degrading bacteria. Process Biochem 2003;38:909-14.

Schmidt JE, Ahring BK. Extracellular polymers in granular sludge from different upflow anaerobic sludge blanket (UASB) reactors. Appl Microbiol Biotechnol 1994;42: 457-62.

Schwarzenbeck N, Erley R, Mc Swain BS, Wilderer PA, Irvine RL. Treatment of malting wastewater in a granular sludge sequencing batch. Acta Hydrochimica 2004a;32: $16-24$.

Schwarzenbeck N, Erley R, Wilderer PA. Aerobic granular sludge in an SBR-system treating wastewater rich in particulate matter. Water Sci Technol 2004b;49:21-46.

Schwarzenbeck N, Borges JM, Wilderer PA. Treatment of dairy effluents in an aerobic granular sludge sequencing batch reactor. Appl Microbiol Biotechnol 2005;66: 711-8.

Sheng GP, Yu HQ. Characterization of extracellular polymeric substances of aerobic sludge using three-dimensional excitation and emission matrix fluorescence spectroscopy. Water Res 2006;40:1233-9.

Snaidr J, Amann R, Huber I, Ludwig W, Schleifer KH. Phylogenetic analysis and in situ identification of bacteria in activated sludge. Appl Environ Microb 1997;63: 2884-96.

Stuermer DH, Ng DJ, Morris CJ. Organic contaminants in groundwater near an underground coal gasification site in northeastern Wyoming. Environ Sci Technol 1982;16:582-7.

Su KZ, Yu HQ. Formation and characterization of aerobic granules in a sequencing batch reactor treating soybean-processing wastewater. Environ Sci Technol 2005;39: 2818-28.

Sutherland IW. Polysaccharases for microbial exopolysaccharides. Carbohydr Polym 1999;38:319-28.

Taniguchi J, Hemmi H, Tanahashi K, Amano N, Nakayama T, Nishim T. Zinc biosorption by a zinc-resistant bacterium, Brevibacterium sp. Strain, HZM-1. Appl Microbiol Biotechnol 2000;54:581-8.

Tay JH, Liu QS, Liu Y. Microscopic observation of aerobic granulation in sequential aerobic sludge blanket reactor. J Appl Microbiol 2001a;91:168-75.

Tay JH, Liu QS, Liu Y. The role of cellular polysaccharides in the formation and stability of aerobic granules. Lett Appl Microbiol 2001b;33:222-6.

Tay JH, Liu QS, Liu Y. The effects of shear force on the formation, structure and metabolism of aerobic granules. Appl Microbiol Biotechnol 2001c;57:227-33.

Tay JH, Liu QS, Liu Y. Characteristics of aerobic granules grown on glucose and acetate in sequential aerobic sludge blanket reactors. Environ Technol 2002a;23:931-6.

Tay JH, Yang SF, Liu Y. Hydraulic selection pressure-induced nitrifying granulation in sequencing batch reactors. Appl Microbiol Biotechnol 2002b;59:332-7.

Tay STL, Ivanov V, Yi S, Zhuang WQ Tay JH. Presence of anaerobic Bacteroides in aerobically grown microbial granules. Microbiol Ecol 2002c;44:278-85.

Tay JH, Liu QS, Liu Y. Shear force influences the structure of aerobic granules cultivated in sequencing batch reactor. 5th International conference on biofilm systems, 14- 19 September, Cape Town, South Africa; 2003.

Tay JH, Pan S, He YX, Tay STL. Effect of organic loading rate on aerobic granulation: Part II. Characteristics of aerobic granules. J Environ Eng 2004a;130:1102-9.

Tay JH, Jiang HL, Tay STL. High-rate biodegradation of phenol by aerobically grown microbial granules. J Environ Eng 2004b;130:1415-23.

Tay STL, Moy BYP, Jiang HL, Tay JH. Rapid cultivation of stable aerobic phenol-degrading granules using acetate-fed granules as microbial seed. J Biotechnol 2005a;115: 387-95.

Tay STL, Moy BYP, Maszenan AM, Tay JH. Comparing activated sludge and aerobic granules as microbial inocula for phenol biodegradation. Appl Microbiol Biotechnol 2005b;67:708-13.

Tay JH, Yang P, Zhuang WQ Tay STL, Pan ZH. Reactor performance and membrane filtration in aerobic granular sludge membrane bioreactor.J Membrane Sci 2008;304: 24-32.

Thayalakumaran N, Bhamidimarri R, Bickers PO. Biological nutrient removal from mea processing wastewater using a sequencing batch reactor. Water Sci Technol 2003;47: 101-8.

Toh SK, Tay JH, Moy BYP, Ivanov V, Tay STL. Size-effect on the physical characteristics of the aerobic granule in a SBR. Appl Microbiol Biotechnol 2003;60:687-95.

Trinet F, Heim R, Amar D, Chang HT, Rittmann BE. Study of biofilm and fluidization of bioparticles in a three-phase fluidized-bed reactor. Water Sci Technol 1991;23: 1347-54.

Tripathi, C.S., . Thermophilic aerobic biological treatment of bleached kraft pulp mill effluent and its effect on floc formation and settleability. Ph.D. Dissertation, University of Toronto, Toronto, Canada. 1999.

Tripathi CS, Allen DG. Comparison of mesophilic and thermophilic aerobic biological treatment in sequencing batch reactors treating bleached kraft pulp mill effluent. Water Res 1999;33:836-46.

Tsuneda S, Nagano T, Hoshino T, Ejiri Y, Noda N, Hirata A. Characterization of nitrifying granules produced in an aerobic upflow fluidized bed reactor. Water Res 2003;37: 4965-73.

Tsuneda S, Ogiwara M, Ejiri Y, Hirata A. High-rate nitrification using aerobic granular sludge. Water Sci Technol 2006;53:147-54.
Valdman E, Leite SGF. Biosorption of $\mathrm{Cd}, \mathrm{Zn}$ and $\mathrm{Cu}$ by Saragssum sp. waste biomass. Bioprocess Eng 2000;22:171-3.

Wang Q Du G, Chen J. Aerobic granular sludge cultivated under the selective pressure as a driving force. Process Biochem 2004;39:557-63.

Wang F, Yang F, Zhang XW, Liu Y, Zhang H, Zhou J. Effects of cycle time on properties of aerobic granules in sequencing batch airlift reactors. World J Microbiol Biotechnol 2005a;21:1379-84.

Wang ZW, Liu Y, Tay JH. Distribution of EPS and cell surface hydrophobicity in aerobic granules. Appl Microbiol Biotechnol 2005b;69:469-73.

Wang ZW, Li Y, Zhou JQ, Liu Y. The influence of short-term starvation on aerobic granules. Process Biochem 2006;41:2373-8.

Wang SG, Liu XW, Gong WX, Gao BY, Zhang DH, Yu HQ. Aerobic granulation with brewery wastewater in a sequencing batch reactor. Bioresour Technol 2007a;98:2142-7.

Wang SG, Liu XW, Zhang HY, Gong WX. Aerobic granulation for 2,4-dichlorophenol biodegradation in a sequencing batch reactor. Chemosphere 2007b;69:769-75.

Wang XH, Zhang HM, Yang FL, Xia LP, Gao MM. Improved stability and performance of aerobic granules under stepwise increased selection pressure. Enzyme Microbiol Technol 2007c;41:205-11.

Watanabe K, Hino S, Takahashi N. Responses of activated sludge to an increase in phenol loading. J Ferment Bioeng 1996;82:522-4.

Weber SD, Ludwig W, Schleifer KH, Fried J. Microbial composition and structure of aerobic granular sewage biofilms. Appl Environ Microbiol 2007;73:6233-40.

Whiteley AS, Bailey MJ. Bacterial community structure and physiological state within an industrial phenol bioremediation system. Appl Environ Microbiol 2000;66: 2400-7.

Wilen BM, Onuki M, Hermansson M, Lumley D, Mino T. Microbial community structure in activated sludge floc analysed by fluorescence in situ hybridization and its relation to floc stability. Water Res 2007. doi:10.1016/j.watres.2007.12.013.

Williams JC, de los Reyes III FL. Microbial community structure of activated sludge during aerobic granulation in an annular gap bioreactor. Water Sci Technol 2006;54: 139-46.

Winter RB, Yen KM, Ensley BD. Efficient degradation of trichloroethylene by a recombinant Escherichia-coli. Biotechnol 1989;7:282-5.

Wuertz S, Okabe S, Hausner M. Microbial communities and their interactions in biofilm systems: an overview. Water Sci Technol 2004;49:327-36.

Xavier J, de Kreuk M, Picioreanu C, van Loosdrecht MCM. Multi-scale individual-based model of microbial and bioconversion dynamics in aerobic granular sludge. Environ Sci Technol 2007;41:6410-7.

Xie S. Metabolic response of aerobic granules to chromium(III). Final year report of Bachelor of Engineering. Singapore: Nanyang Technological University; 2003.

Xu H, Tay JH, Foo SK, Yang SF, Liu Y. Removal of dissolved copper(II) and zinc(II) by aerobic granular sludge. Water Sci Technol 2004;50:155-60.

Yang SF, Liu Y, Tay JH. A novel granular sludge sequencing batch reactor for removal of organic and nitrogen from wastewater. J Biotechnol 2003;106:77-86.

Yang SF, Liu QS, Tay JH, Liu Y. Growth kinetics of aerobic granules developed in sequencing batch reactors. Lett Appl Microbiol 2004a;38:106-12.

Yang SF, Tay JH, Liu Y. Inhibition of free ammonia to the formation of aerobic granules. Biochem Eng J 2004b; 17:41-8

Yang SF, Tay JH, Liu Y. Respirometric activities of heterotrophic and nitrifying populations in aerobic granules developed at different substrate N/COD ratios. Curr Microbiol 2004c;49:42-6.

Yang Z, Peng XF, Chen MY, Lee DJ. Intra-layer flow in fouling layer on membranes. J Membrane Sci 2007;287:280-6.

Yang SF, Li XY, Yu HQ. Formation and characterisation of fungal and bacterial granules under different feeding alkalinity and $\mathrm{pH}$ conditions. Process Biochem 2008;43:8-14.

Yi S, Tay JH, Maszenan AM, Tay STL. A culture-independent approach for studying microbial diversity in aerobic granules. Water Sci Technol 2003;47:283-90.

Yi S, Zhuang WQ Wu B, Tay ST, Tay JH. Biodegradation of p-nitrophenol by aerobic granules in a sequencing batch reactor. Environ Sci Technol 2006;40:2396-01.

Zhang XQ Bishop PL. Biodegradability of biofilm extracellular polymeric substances. Chemosphere 2003;50:63-9.

Zhang LL, Feng XX, Zhu NW, Chen JM. Role of extracellular protein in the formation ADN stability of aerobic granules. Enzymes Microb Technol 2007. doi:10.1016/j. enzmictec.2007.05.001.

Zhang LL, Chen JM, Fang F. Biodegradation of methyl $t$-butyl ether by aerobic granules under a cosubstrate condition. Appl Microbiol Biotechnol 2008;78:543-50.

Zheng YM, Yu HQ, Sheng GP. Physical and chemical characteristics of granular activated sludge from a sequencing batch airlift reactor. Process Biochem 2005;40:645-50.

Zheng YM, Yu HQ Liu SJ, Liu XZ. Formation and instability of aerobic granules under high organic loading conditions. Chemosphere 2006;63:1791-800.

Zhu J. Reply to comment by J. Zhu. Water Res 2004;38:3467-9.

Zhu J, Wilderer PA. Effect of extended idle conditions on structure and activity of granular activated sludge. Water Res 2003;37:2013-8.

Zhu L, Xu X, Luo W, Cao D, Yang Y. Formation and microbial community analysis of chloroanilines-degrading aerobic granules in the sequential airlift bioreactor. J Appl Microbil 2008;104:152-60.

Zita A, Hermansson M. Determination of bacterial cell surface hydrophobicity of single cells in cultures and in wastewater in situ. FEMS Microbiol Lett. 1997;18:299-06. 